\title{
OECDpublishing
}

\section{GENDER INEQUALITY IN WEST AFRICAN SOCIAL INSTITUTIONS}

\section{WEST AFRICAN PAPERS}

March 2018 No. 13 



\section{GENDER INEQUALITY IN WEST AFRICAN SOCIAL INSTITUTIONS}

This paper has been prepared by

NEJMA BOUCHAMA

GAËLLE FERRANT

LÉA FUIRET

ALEJANDRA MENESES

ANNELISE THIM

OECD Development Centre's Gender team 


\section{WEST AFRICAN PAPERS}

The West African Papers series explores African socio-economic, political and security dynamics from a regional and multidisciplinary perspective. It seeks to stimulate discussion and gather information to better anticipate the changes that will shape future policies. The series is designed for a wide audience of specialists, development practitioners, decision makers and the informed public. Papers are available in English and/or French, and summaries are available in both languages. Initiated by the Sahel and West Africa Club (SWAC) to highlight and promote West African issues, the work presented is prepared by its Secretariat, Members and partners, other OECD departments, related international organisations, associated experts and researchers.

For more information on the Sahel and West Africa Club: http://www.oecd.org/swac.

Please cite this publication as:

Bouchama, N., G. Ferrant, L. Fuiret, A. Meneses and A. Thim (2018), “Gender Inequality in West African Social Institutions", West African Papers, No. 13, OECD Publishing, Paris. https://doi.org/10.1787/fe5ea0ca-en

Author contact: gaelle.ferrant@oecd.org

ISSN 2414-2026

OECD Working Papers should not be reported as representing the official views of the OECD or of its member countries. The opinions expressed and arguments employed are those of the authors.

This document and any map included herein are without prejudice to the status of or sovereignty over any territory, to the delimitation of international frontiers and boundaries and to the name of any territory, city or area.

Working Papers describe preliminary results or research in progress by the author(s) and are published to stimulate discussion on a broad range of issues on which the OECD works. Comments on Working Papers are welcomed, and may be sent to the Sahel and West Africa Club, OECD, 2 rue André-Pascal, 75775 Paris Cedex 16, France.

Authorised for publication by Laurent Bossard, Director, Sahel and West Africa Club Secretariat (SWAC/OECD).

(C) OECD 2018

You can copy, download or print OECD content for your own use, and you can include excerpts from OECD publications databases and multimedia products in your own documents, presentations, blogs, websites and teaching materials, provided that suitable acknowledgment of OECD as source and copyright owner is given. All requests for commercial use and translation rights should be submitted to rights@oecd.org. 


\begin{abstract}
Discriminatory social institutions - formal and informal laws, social norms and practices - restrict women's rights and empowerment opportunities across 17 West African countries. New laws and measures to protect and promote women's economic, political and human rights have been accompanied by impressive reductions in gender gaps. However, discriminatory social institutions still constitute significant impediments to women's access to land assets and restrict women's physical integrity and decision-making power in both private and public spheres. This holds back women's education and economic empowerment, thereby decreasing countries' potential growth. The data and analysis based on the OECD Development Centre's Social Institutions and Gender Index (SIGI) aims to provide policy makers with the necessary tools and evidence to design more effective gender-responsive policies. Putting social institutions at the core of policy responses may open new and sustainable vistas to promote gender equality in national and regional development agendas.
\end{abstract}

Keywords: women, social institutions, gender inequality, West Africa JEL Classification: J16, K38, N37

\title{
ACKNOWLEDGEMENTS
}

This paper has been prepared at the request and with the financial support of the Sahel and West Africa Club. The OECD Development Centre would like to thank the SWAC/ OECD Secretariat for their co-operation, feedback and expertise, in particular to Nadia Hamel, who co-ordinated this paper, and Marie Trémolières. The authors are grateful to Joël Boutroue, Bathylle Missika and Lorenzo Pavone (OECD Development Centre) for their useful comments and to Julie Bousquet for her support. 


\section{TABLE OF CONTENTS}

EXECUTIVE SUMMARY

RESTRICTED PHYSICAL INTEGRITY .................................................................. 13

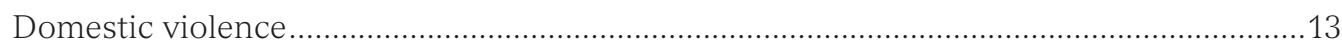

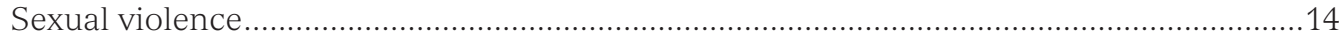

Female genital mutilation ..............................................................................................15

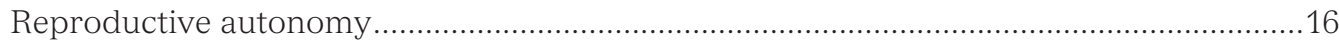

RESTRICTED ACCESS TO RESOURCES AND ASSETS............................................. 17

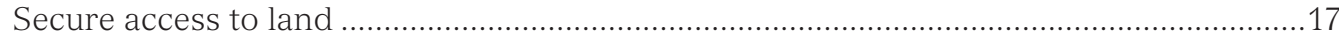

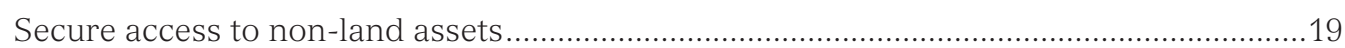

Access to financial services ......................................................................................... 19

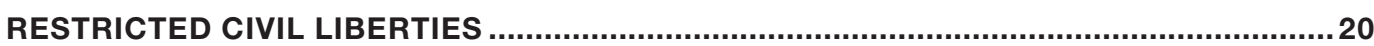

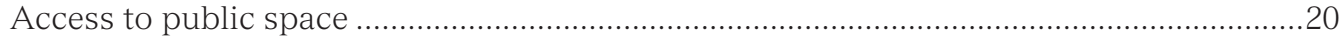

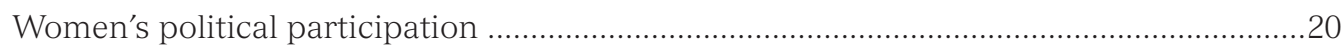

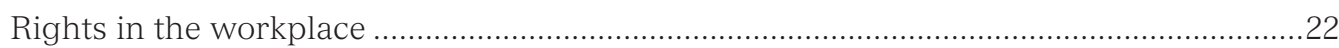

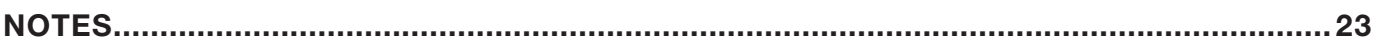

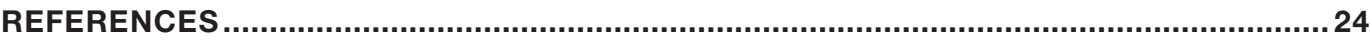

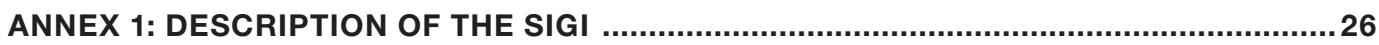

ANNEX 2: SIGI RESULTS PER SUB-INDEX FOR WEST AFRICAN COUNTRIES ............... 27

ANNEX 3: RATIFICATIONS OF GLOBAL AND REGIONAL PROTOCOLS ON GENDER

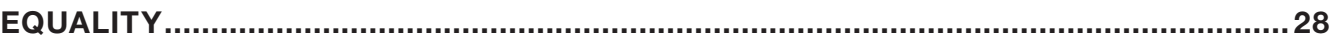

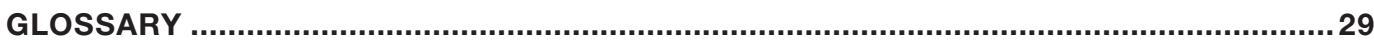




\section{EXECUTIVE SUMMARY}

This paper analyses the Social Institutions and Gender Index (SIGI) results for 17 West African countries ${ }^{1}$ through the dimensions of discriminatory family code, restricted physical integrity, restricted resources and assets and restricted civil liberties (Figure 1). ${ }^{2}$ It explores how legislative reforms and efforts to transform discriminatory social institutions can be translated into positive changes for women and their communities, identifies remaining challenges and highlights the need for a more dedicated policy focus to promote gender equality and women's empowerment.

Restricting women's empowerment opportunities and outcomes holds economies back from experiencing growth and prosperity. Gender parity is not only a fundamental human right but it is also an immense economic opportunity: economies are more resilient, productive and inclusive when they reduce gender inequalities and actively support the equal participation of women and girls in all spheres of life (Ferrant and Kolev, 2016; World Bank, 2012).

By adopting the Sustainable Development Goals (SDGs), particularly Goal 5², governments worldwide, including in West Africa, recognised and agreed on the necessity of achieving gender equality and empowering women and girls. While important advancements have been attained in recent years in West Africa, the road to gender equality faces many persistent challenges. These include discriminatory social institutions that impede women's empowerment and well-being, thereby limiting the development potential of West African economies.

\section{Key messages}

1. Putting social norm change at the core of future efforts could be one of the most effective means for guaranteeing that West Africa is on track to ensure inclusive development. Addressing the challenges presented by discriminatory social institutions will require that West African countries adopt policy responses that are evidence-based, context-specific and consider gender-differentiated impacts.

2. It is urgent to continue building the evidence base on both the extent and nature of discriminatory social institutions. Measuring allows to make visible the invisible and facilitate a better understanding of "what works" in transforming discriminatory social institutions, while considering local realities. This also allows governments to better understand the linkages between discriminatory social institutions, women's empowerment and development outcomes. Strengthening national statistical and analytical capacities will enable governments to both measure and track gender equality as well as capture changes in social institutions and gender roles. 
1. Gender-based discrimination in social institutions is estimated to represent a loss of USD 120 billion in income for the region. Gender equality is gaining ground as "smart economics". Discriminatory social institutions negatively impact economic growth and social well-being, by restricting women's access to education and job opportunities. Globally, the income loss associated with current levels of gender discrimination in social institutions is estimated at over USD 12 trillion, or an equivalent of 16\% of current global GDP (Ferrant and Kolev, 2016).

2. Discriminatory norms and practices within the family exacerbate gender gaps. Early marriage limits girls' ability to pursue and complete further studies and seek gainful employment. Its prevalence is associated with poorer education completion rates but also with poorer health outcomes for girls. Yet, despite signs that rates of early marriage are declining, its prevalence remains double the world average of $13 \%$, with $30 \%$ of West African girls aged 15-19 either married, divorced or widowed.

3. Harmful practices that negatively impact the physical integrity of women are deeply embedded in social norms. Despite programmes aiming at tackling female genital mutilation (FGM), entrenched acceptance by communities, including the acceptance by women, undermines progress. Half of West African women are affected by FGM (DHS, n.d.). The highest rates are found in Guinea and Mali, where nine in ten women have been subjected to the practice. Furthermore, three in four women in these areas believe that FGM should continue (DHS, n.d.).

4. Contrasts between customary laws and legal frameworks weaken women's rights related to land access. Even where women's land rights are legally guaranteed, discriminatory customs and practices restrict their ability to own, control, inherit, manage and make decisions over land. In seven West African countries ${ }^{4}$, women represent, on average, $43 \%$ of agricultural workers but only $8 \%$ of landowners (FAO, 2011).

5. Women's political participation is increasing in West Africa but remains below the global average. Seven countries ${ }^{5}$ have instituted quotas at either the national and/or sub-national levels to promote women's political participation. Nevertheless, women's parliamentary representation in the region only increased from 13\% in 2007 to almost 16\% in 2017 and there are wide discrepancies between countries, with parliamentary representation rates ranging from 43\% in Senegal to $6 \%$ in Nigeria (IPU, 2017).

Figure 1

The composition of the SIGI

Social Institutions and Gender Index

\begin{tabular}{|c|c|c|c|c|}
\hline $\begin{array}{l}\text { Discriminatory } \\
\text { family code }\end{array}$ & $\begin{array}{l}\text { Restricted physical } \\
\text { integrity }\end{array}$ & Son bias & $\begin{array}{l}\text { Restricted resources } \\
\text { and assets }\end{array}$ & $\begin{array}{l}\text { Restricted civil } \\
\text { liberties }\end{array}$ \\
\hline $\begin{array}{l}\text { - Legal age of marriage } \\
\text { - Early marriage } \\
\text { - Parental authority } \\
\text { - Inheritance }\end{array}$ & $\begin{array}{l}\text { - Violence against women } \\
\text { - Female genital mutilation } \\
\text { - Reproductive autonomy }\end{array}$ & $\begin{array}{l}\text { - Missing women } \\
\text { - Fertility preferences }\end{array}$ & $\begin{array}{l}\text { - Secure access to land } \\
\text { - Secure access } \\
\text { to non-land assets } \\
\text { - Access to financial } \\
\text { services }\end{array}$ & $\begin{array}{l}\text { - Access to public space } \\
\text { - Political voice }\end{array}$ \\
\hline
\end{tabular}




\section{AN OVERVIEW}

\section{Te overall SIGI results reflect the poor performance of West African countries in reducing gender discrimination in social institutions:}

- $\quad$ Three countries (Guinea-Bissau, Senegal and Togo) exhibit medium levels of discrimination in social institutions compared to the global average. They are characterised by contradictory legal frameworks marked by plural legal systems (the co-existence of statutory and customary laws) and customary practices perpetuating discrimination.

- $\quad$ Five countries (Benin, Burkina Faso, Côte d'Ivoire, Ghana and Guinea) exhibit high levels of discrimination. In these countries, discrimination in customary laws, social norms and practices is reflected in inappropriate legal protection against gender discrimination.

- The eight remaining countries (Chad, Gambia, Liberia, Mali, Mauritania, Niger, Nigeria and Sierra Leone) have very high levels of discrimination. In addition to highly discriminatory legal frameworks and very poor implementation measures, customary practices and social norms deny women's rights (Map 1). ${ }^{6}$

Map 1

SIGI ranking for West African countries

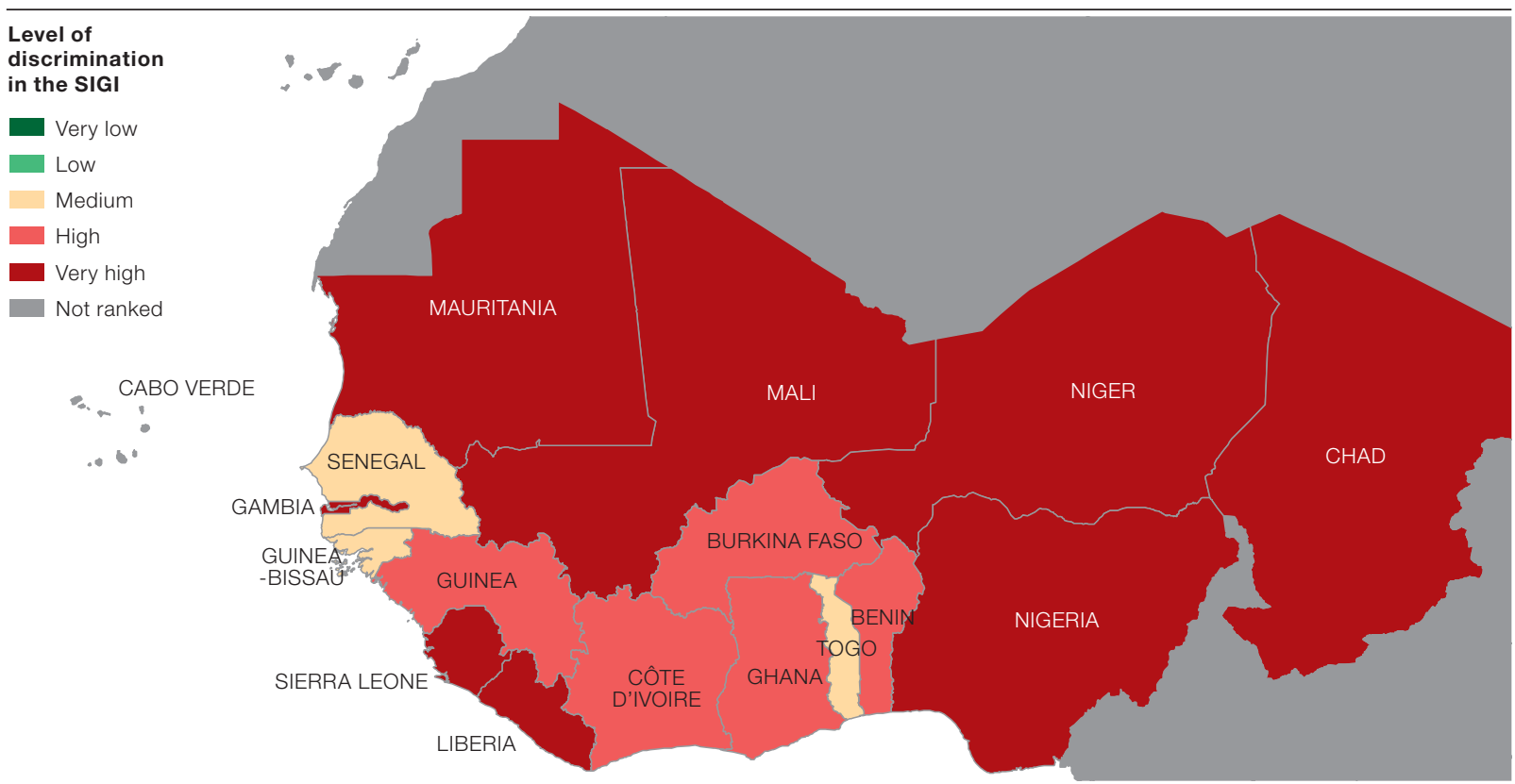

Source: OECD (2014a), Gender, Institution and Development Database, http://stats.oecd.org

West African women face very high levels of discrimination in three dimensions (Figure 2):

- Discriminatory family code: Half of the countries in the region hold negative attitudes with regard to women's inheritance, marriage and divorce, and national constitutions do not always provide women the same rights as men. Five countries (Chad, Gambia, Mauritania, Niger and Nigeria) do not guarantee the same inheritance rights to widows and widowers. While the remaining countries do guarantee equal rights, traditional or religious practices discriminate against widows and daughters. For instance, widows in Liberia have the same rights to inherit assets as widowers but accusations of witchcraft can be used to prevent widows from inheriting assets. Such accusations often occur when the deceased husband was wealthier than the widow (Immigration and Refugee Board of Canada, 2013). In some villages of western Côte d'Ivoire, for instance, when a man who has only daughters dies, his brother will inherit his assets (FAO, 2011). 
- Restricted physical integrity: Another area of concern is the poor coverage and quality of legal protection and other measures to protect women from violence (rape, sexual harassment and domestic violence), female genital mutilation (FGM), as well as the poor guarantee of their sexual and reproductive health and rights. On average, 18\% of women have experienced gender-based violence in their lifetime in Nigeria, and up to 57\% in Chad. This practice is socially accepted: $50 \%$ of women agree that domestic violence is justified on certain grounds.

- Restricted access to resources and assets: Women's rights and access to land, assets and financial services are compromised by discriminatory laws and practices that prevent women from owning, controlling or having decisionmaking power over such critical resources for their economic empowerment. Only in Liberia and Mali do legal frameworks exist which guarantee women and men the same rights to access formal financial services.

However, governement commitments to promoting women's political voice have paid off, particularly in Mauritania and Senegal which showed the lowest levels of discrimination in civil liberties. Mauritania's constitution provides citizens with equal rights in voting and holding public office and ensures the participation of women in the public sphere and in politics. Thirty-one percent of Mauritania's ministerial positions and 25\% of its parliamentary seats are held by women (IPU, 2017). In 2010, Senegal introduced a law establishing full gender parity in all fully or partially elected bodies (CEDAW, 2014), and in 2017, it ranked $7^{\text {th }}$ in the world in terms of women's representation in parliament (47\%).

Figure 2

SIGI West Africa average, best and poorest performers

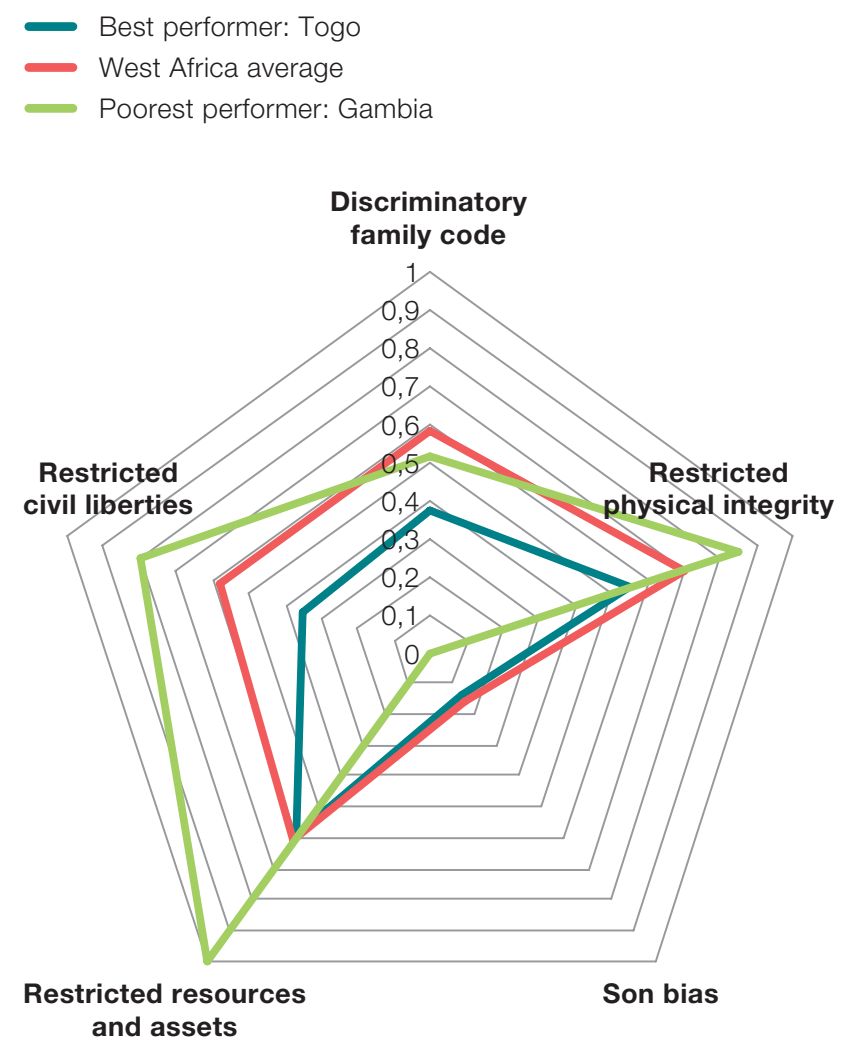

Notes: This figure presents SIGl sub-index scores of the regional average, along with the best (Togo) and the poorest (Gambia) performers. Higher SIGI values indicate higher inequality: The SIGI ranges from 0 for low discrimination to 1 for very high discrimination. Source: OECD (2014a), Gender, Institution and Development Database, http://stats.oecd.org. 


\section{DISCRIMINATORY FAMILY CODE}

$\mathrm{T}$ his sub-index captures social institutions that limit women's decision-making power and their status in the household and family. These formal and informal laws, social norms and practices co-exist in different types of legal systems, including civil or common law, customary law and religious laws, and they cover areas such as marriage, parental authority and inheritance.

Eleven countries (Burkina Faso, Chad, Côte d'Ivoire, Gambia, Ghana, Liberia, Mali, Mauritania, Niger, Nigeria and Senegal) classified as having high to very high levels of discrimination and no country positioned at the very low level despite strengthened national legislative frameworks and regional commitments.

\section{Early marriage}

Countries have ratified legal frameworks against the practice of early marriage. All countries are signatories of the Protocol to the African Charter on Human and Peoples' Rights on the Rights of Women in Africa, the African Youth Charter (Article 8) and the African Charter on the Rights and Welfare of the Child (Article 21). Notable changes in national legal frameworks include Gambia's Children's Amendment Bill (2016), which criminalises child marriage and child betrothal and sentences persons convicted of such offenses to 20 years of imprisonment (US Department of State, 2017).

Legal loopholes and customary practices weaken women's rights. In 11 countries, girls can still marry under the age of 18 (OECD, 2014a). ${ }^{7}$ Even when such legislation exists, it might be weakened by the existence of plural legal systems. Thus, while the legal age of marriage may be 18 under the civil code, other legal regimes that regulate marriage, namely customary and religious laws, may allow early marriages to continue in certain countries (e.g. Gambia, Ghana, Mauritania and Nigeria).

National campaigns and action plans are evidence of a country's political will to end early marriage. Ghana launched a national campaign to end child marriage, which led to the establishment in 2016 of the Child Marriage Co-ordinating Unit of the Ministry of Gender, Children and Social Protection. A 10-year national strategic framework, which included the Ending Child Marriage Campaign, was launched. In 2015, Burkina Faso's Ministry of Women, National Solidarity and the Family, together with the UN and civil society organisations, created a road map to Fight Child Marriage and Female Genital Mutilation (2016-18). This road map includes four objectives, namely: 1) co-ordination, follow-up and monitoring; 2) social mobilisation and advocacy; 3) capacitybuilding for actors; and 4) multi-sectorial responses (MFASSN, 2015).

Despite a slight decrease, the prevalence of this practice remains a major concern. The rate of early marriage is more than double the world average (13\%), with $30 \%$ of girls aged 15-19 married, divorced, widowed or in informal unions. Seven of the 20 countries with the highest rates of early marriage in the world are found in West Africa (Burkina Faso, Chad, Guinea, Mali, Niger, Nigeria and Sierra Leone), with rates reaching as high as $76 \%$ in Niger. However, most countries have seen a slight decrease in recent years in the percentage of women married before the age of 18 (Figure 3). Gambia has experienced the largest decrease, with a difference of 28 percentage points between women aged 45-49 (58\% reported having been married before the age of 18) and women aged 20-24 (30\%) in 2013. 
Figure 3

Early marriage prevalence remains high across age cohorts in West Africa

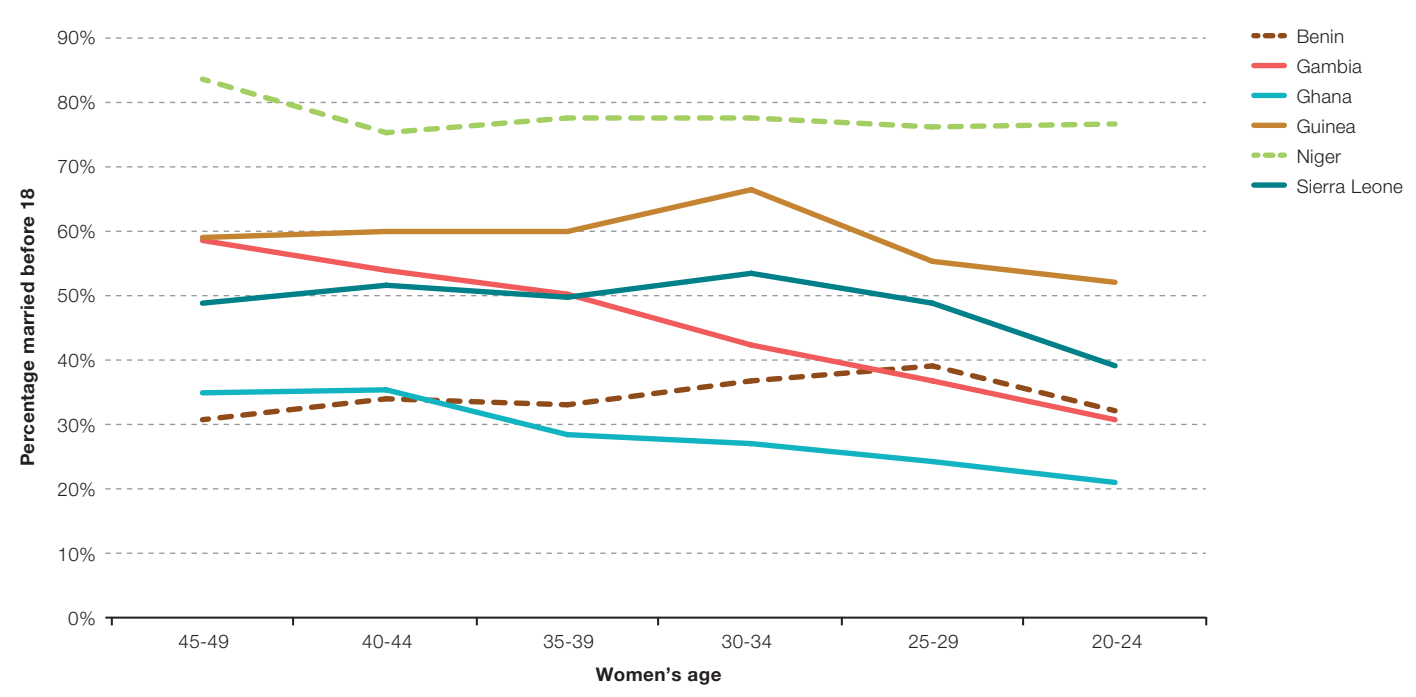

Note: This figure presents the percentage of women married before the age of 18 by age cohort and by country.

Source: Demographic and Health Surveys (1988-2015), http://dhsprogram.com/data/.

Early marriage is linked to socio-economic factors. In Benin, girls living in rural areas are two-and-a-half times more likely to be married before the age of 18 than girls living in urban areas (Girls not Brides, n. d.). Girls from the poorest families in Senegal are four times more likely to be married early than girls from the richest families (UNICEF, 2015). The traditional practice of early marriage benefits the girl's family both socially and financially. The persistence of this practice is also explained by favourable opinions towards early marriage in some areas. In Burkina Faso, for example, $44 \%$ of the population think it is acceptable for a girl to be married before the age of 18 , while only $4 \%$ believe it is acceptable for a boy (OECD, 2018).

\section{Parental authority}

De jure discrimination continues to restrict women's rights in parental authority over their children. Only five countries (Benin, Burkina Faso, Côte d'Ivoire, Gambia and Sierra Leone) grant women and men equal legal parental authority both during marriage and after divorce. Legal restrictions on women's parental authority during and after marriage remain in four countries (Chad, Guinea, Mali and Mauritania). Such restrictions include recognising the husband as the sole head of the household (Mali) or granting parental authority solely to the father (Mauritania).

Even when equal rights are legally guaranteed, women continue to face de facto discrimination. Laws guaranteeing equal rights are often contradicted by customary, traditional or religious practices (Guinea-Bissau, Nigeria and Togo). In civil marriages in Nigeria, the mother and father share parental authority, and married couples jointly share legal responsibility for financially maintaining the family's expenses. Married and unmarried women can be head of the household in the same way as men. However, at least two-thirds of the Nigerian population are bound by customary and religious law that grants solely to men the status of head of the household and parental authority. 


\section{Box 1}

Early marriage and girls' secondary education in West Africa

In countries with a high prevalence of early marriage, girls have lower secondary education enrolment and completion rates (OECD Development Centre, 2014) (Figure 4). Furthermore, early marriage is also associated with poorer health outcomes for girls and their children, as well as higher fertility rates. Girls who marry early are more likely to bear children at a young age. In Niger, $76 \%$ of women aged $20-24$ had been married before the age of 18 and $48 \%$ had had a child before the age of 18 (UNICEF, 2015). In addition, social acceptance of early marriage and pregnancy, limited access to contraception and the prevalence of sexual violence contribute to higher adolescent fertility rates. In turn, early pregnancy cuts short girls' education and explains persistent gaps in educational attainment between girls and boys at the secondary school level.

Figure 4

Higher prevalence of early marriage of girls, lower female secondary education

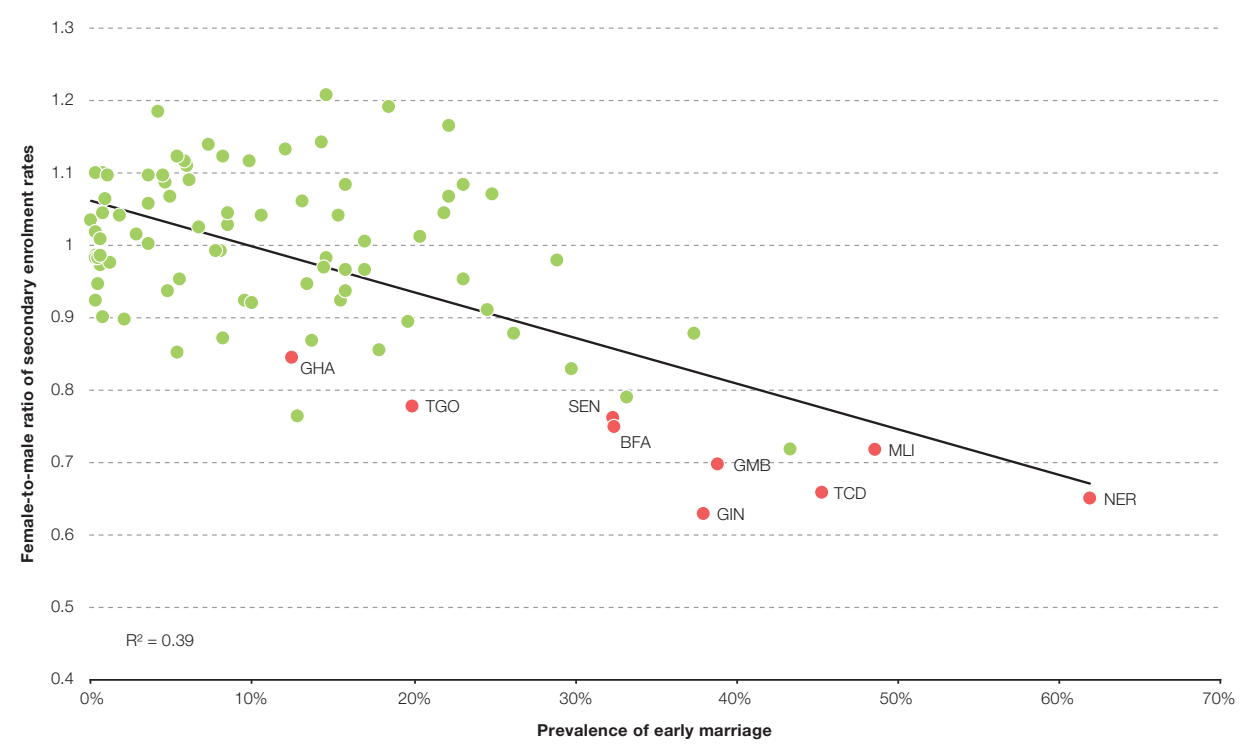

Note: This figure shows the relationship between female-to-male ratio of secondary education enrolment rates and levels of early marriage prevalence for girls in 88 countries, controlling for each country's GDP per capita, proportion of female teachers, government expenditure in education, gender gap in unemployment, urbanisation rate and regional dummies. $\mathrm{R}^{2}=0.39$ means that $39 \%$ of regional disparities in female secondary education completion are explained by regional differences in the prevalence of early marriage for girls.

Source: OECD (2014a) Gender, Institutions and Development Database, http://stats.oecd.org; World Bank (n.d.) World Development Indicators (database), http://data.worldbank.org.

\section{Inheritance rights}

In the majority of countries, women face discrimination when claiming their inheritance rights. The legal right to inheritance for widows and daughters is protected in all but five countries (Chad, Gambia, Mauritania, Niger and Nigeria). Recent positive legal changes include Togo's Personal and Family Code in 2012, which provides widows and daughters with the same rights. Nevertheless, in some countries, inheritance is governed by customary and religious laws that prohibit women from inheriting property (Chad), and property is thus passed to male heirs (Guinea-Bissau). In Mali, the inheritance law is often tempered by the view that women are less responsible and reliable than men and that they are therefore less suited to inheriting family property. As a result, women rarely inherit land when the inheritance is divided among successors. 
Levirate marriage is a practice designed to keep patrilineal property together and to ensure that custody of the children remains within the paternal family. This practice in which a widow is obliged to marry her deceased husband's brother is common in West Africa and remains legal under certain customary laws (e.g. Benin and Mali). In other communities, when a woman dies, her younger sister is expected to marry the widower that is called sororate.

For seven countries in the region, only $43 \%$ of widows report inheriting any assets, and even fewer (27\%) report inheriting the majority of assets. In six of the seven countries surveyed (Benin, Guinea, Mali, Niger, Nigeria and Sierra Leone), the deceased spouse's children or family inherited the majority of assets (Figure 5). Only in Senegal were widows most likely to inherit the majority of assets (46\%).

Figure 5

Who inherits the majority of assets? Inheritance practices in selected countries

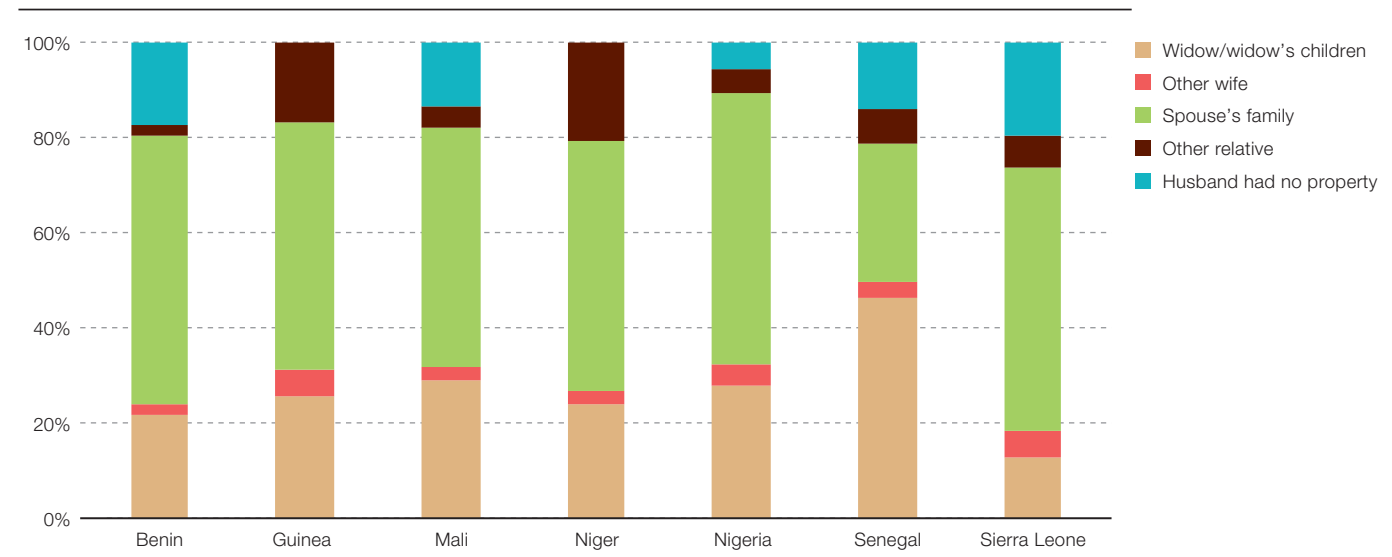

Notes: This figure presents the percentage of cases in which the deceased man's family inherits the majority of assets for selected countries. The sample is taken from among women aged 15-49, and mean values are weighted according to population-level weights provided in the DHS.

Source: Demographic and Health Surveys (1988-2015), http://dhsprogram.com/data.

\section{Divorce}

The majority of countries have legislation granting women the right to initiate divorce, though two countries (Mauritania and Niger) still legally discriminate against women in this regard. A Mauritanian women may request a divorce only on the grounds of damages or injuries, but owes compensation if she is wrong (art. 102). A husband, however, has the right of repudiation (unilateral divorce by the husband), allowing him to divorce his wife at any time without being obliged to claim a reason or to provide any compensation.

Nevertheless, discriminatory customs or religious practices in eight countries (Chad, Gambia, Guinea, Liberia, Mali, Nigeria, Senegal and Togo) negatively affect women's ability to claim their legal rights. In Mali, either spouse may petition for divorce but women rarely initiate proceedings because of strong social pressure and fears of losing custody of their children. Togolese women can file for divorce under the same conditions as men and the new Personal and Family Code introduces and establishes divorce by mutual consent. Nonetheless, in rural areas where customary marriages dominate, repudiation is the most common form of divorce, and women have no rights to maintenance or child support. Repudiated women lose custody of their children and are forced to return to their parents' home, leaving all their possessions behind. 


\section{RESTRICTED PHYSICAL INTEGRITY}

$\mathbf{T}$ his sub-index captures social institutions that limit the control women and girls exercise over their bodies, increase women's vulnerability and normalise genderbased violence. These include formal and informal laws, norms and practices that fail to protect women's physical integrity and reproductive autonomy and allow violence and female genital mutilation (FGM).

Fifteen countries (Benin, Burkina Faso, Chad, Côte d'Ivoire, Gambia, Ghana, Guinea, Guinea-Bissau, Liberia, Mali, Mauritania, Nigeria, Senegal, Sierra Leone and Togo) classified as having high to very high levels of discrimination. While countries have increased women's legal protection, legislative gaps remain, particularly concerning domestic violence. Social acceptance for justifying violence against women are reflected in high acceptance rates among women themselves. Conflicts increase women's vulnerability to gender-based violence and limit their ability to seek justice.

Women and girls' physical integrity is still threatened by FGM despite strengthened regional commitments. The Protocol to the African Charter on Human and Peoples' Rights on the Rights of Women in Africa (Maputo Protocol) (2003) calls on states to adopt appropriate measures to ensure women's protection from all forms of violence and harmful practices, including FGM. It has been ratified by 14 out of 17 West African countries, with the remaining three countries having signed but not ratified it (Chad, Niger and Sierra Leone). Nevertheless, there is slow progress in eliminating FGM.

\section{Domestic violence}

Legal loopholes justify customary practices increasing women's physical vulnerability. Eight of the 17 countries (Burkina Faso, Chad, Côte d'Ivoire, Gambia, Liberia, Mali, Mauritania and Niger) do not have national legislations in place. Existing laws often provide only partial coverage for women. For example, Senegal excludes sexual, emotional or economic violence, Gambia and Mauritania fail to recognise marital rape.

\section{Figure 6}

The relationship between women's acceptance of domestic violence and prevalence rates (regardless of the existence of a legal framework)

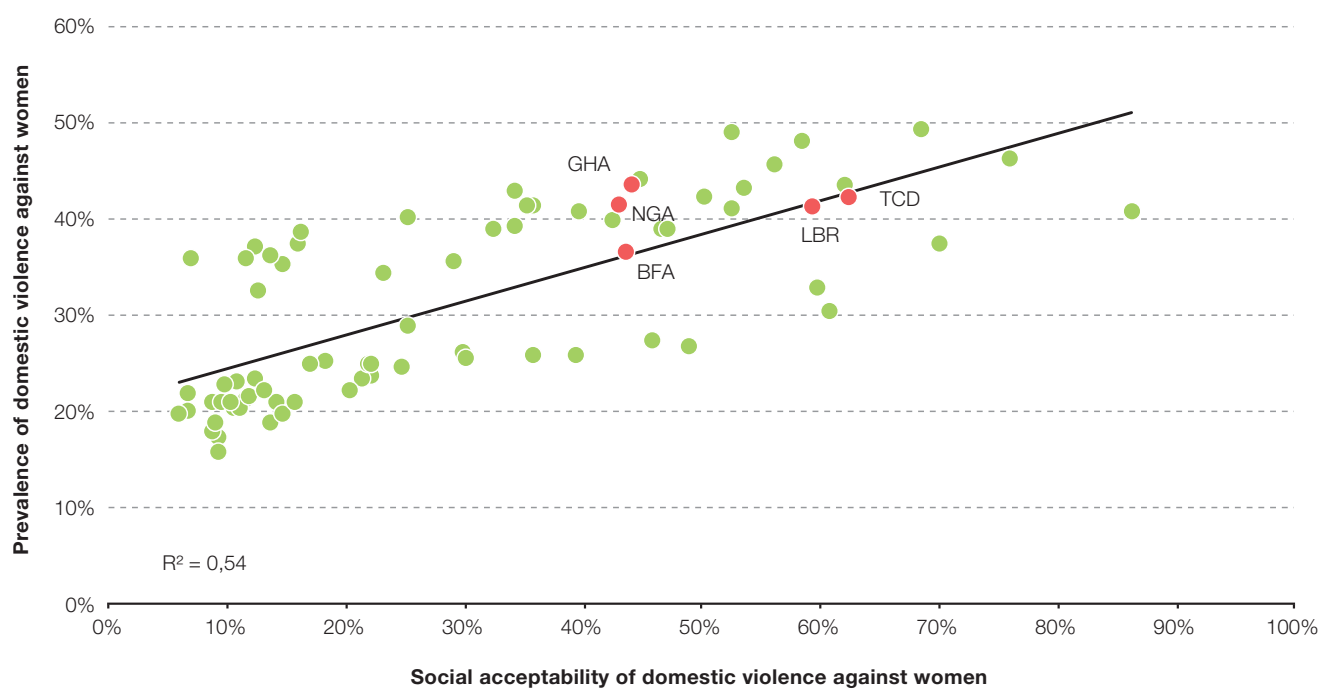

Note: This figure presents the relationship between the social acceptability of domestic violence (as measured by the share of women declaring that a husband is justified in beating his wife under certain circumstances) and the prevalence of domestic violence against women (as measured by the share of women aged 15-49 declaring that they have been victims of physical and/ or sexual violence from an intimate partner in their lifetime). These figures control for income and regional dummies, as well as the SIGI score for the existence of laws addressing domestic violence against women. $R^{2}=0.54$ means that $54 \%$ of country disparities in the prevalence of domestic violence are explained by differences in the acceptance of domestic violence.

Source: OECD (2014a), Gender, Institutions and Development Database, http://stats.oecd.org. 
Domestic violence remains common and widely justified by social norms. On average, $18 \%$ of women in Nigeria report having experienced physical or sexual violence from an intimate partner at some point in their lives; this figure is up to 57\% in Sierra Leone (OECD, 2014a). Fifty seven percent of women believe that their husbands or partners are justified in beating them under certain circumstances; this figure is up to $92 \%$ in Guinea. Social norms justifying violence against women help explain the high prevalence rates of domestic violence, even in countries with adequate legislation: higher prevalence corresponds with higher levels of social acceptance. In Nigeria, 18\% of women report experiencing intimate partner violence in their lifetime, and $43 \%$ accept the harmful practice, while in Chad, these numbers are considerably higher: $57 \%$ of women have been victims, and $62 \%$ accept the practice (Figure 6).

\section{Sexual violence}

Large gaps remain in legislation. While the majority of countries have legislation on rape, only three (Benin, Burkina Faso and Ghana) have comprehensive laws that cover marital rape and do not drop criminal charges if perpetrators marry their victims. Even in these three countries enforcement is ineffective. In the remaining 14 countries, legislation addressing rape contains legal loopholes for perpetrators. Indeed, 10 countries exclude marital rape.

However, laws are weakly enforced and programmes lack resources. In Côte d'Ivoire, a special budget for enforcement was created as part of its National Strategy for Combating Gender-based Violence (MSFWC, 2014). This is an exception. Generally, even when perpetrators are arrested, their cases may not be investigated or may be dropped by the courts before a verdict is reached (US Department of State, 2012). Specialised training for police officers, as well as for the justice sector and health professionals, can help address the issue. In Nigeria, UN Women held training sessions for police officers and helped draft the country's Gender Policy for the National Police Force (2009). In Guinea, the government initiated a capacity-building programme in medical care and counselling for medical and healthcare staff and set up hotlines for survivors of rape and sexual violence (MSAAWC, 2014). Governments in the region have recognised the need for a holistic approach to support the specific needs of survivors of violence.

Stigmatisation and denial of women's rights reinforce discriminatory social institutions. In Mali, 78\% of women aged 15-49 declare that a woman is not justified in refusing sex with her husband, compared to $5 \%$ in Chad. Stigmatisation within the justice system may deter women from asserting their rights. In Nigeria and Senegal, police are unwilling to intervene in cases of domestic violence because it is perceived to be a private matter (OECD, 2014b).

Conflicts exacerbate women's vulnerability. During the 2001 crisis in Côte d'Ivoire, $67 \%$ of women in the country became victims of gender-based violence (AfDB, 2013). In 2007, Côte d'Ivoire was the first post-conflict country to adopt a National Action Plan on the implementation of the United Nations Security Council Resolution 1325 (UNSCR 1325) on Women, Peace and Security, followed by Liberia in 2009. In Liberia, specialised prosecution units of the Ministry of Justice deal with sexual and gender-based violence cases (UN Women, 2015).

Women lack comprehensive legal protection from sexual harassment. While nearly half of the countries (8 out of 17) have laws addressing some form of sexual harassment, most laws are limited in the areas where they protect women. In five countries (Burkina Faso, Côte d'Ivoire, Niger, Senegal and Togo), the legislation only covers sexual harassment in the workplace. Only four countries (Benin, Cabo Verde, Gambia and Nigeria) address sexual harassment in educational settings, and two (Benin and Guinea-Bissau) cover public spaces (World Bank, 2015). 


\section{Box 2}

Maternal mortality and missing women in West Africa

In other regions (East Asia and the Pacific, Central Asia and the Caucasus and South Asia) with evidence of missing women (very low proportion of women in the population), skewed sex ratios are linked to sex-selective abortions and infanticide. In West Africa, sex ratios at birth follow natural expectations and therefore show no strong evidence of sons bias (Figure 7). Instead, female mortality is most alarming within the 15-60 year old cohort, particularly in the 15-49 age range.

Figure 7

Sex ratios by age cohort

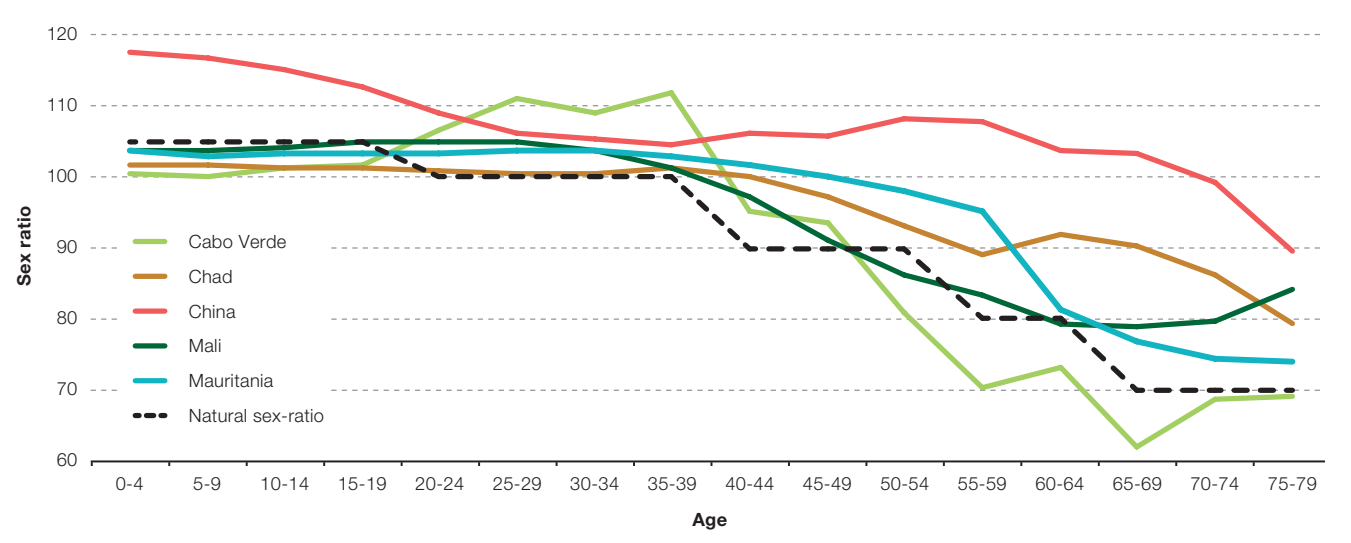

Note: This figure presents the male-to-female sex ratio (the number of males per 100 females), by age cohort. Source: United Nations (2015c).

This is explained by high rates of maternal mortality. These rates decreased from 1132 deaths per 100000 live births in 1990 to 678 in 2015 but remain more than triple the world's average of 216 (World Bank, n.d.). In Chad and Sierra Leone, women face the greatest risk of dying from pregnancy-related complications, with maternal death rates of 1 in 18 and 1 in 17, respectively, compared with the global average of 1 in 180 (World Bank, n.d.). Only in Cabo Verde is the lifetime risk of maternal death lower than the global average (1 in 900).

\section{Female genital mutilation}

While the number of national legal frameworks has increased, they vary in scope and enforcement mechanisms. In all countries but four (Cabo Verde - where FGM has no cultural roots -, Liberia, Mali and Sierra Leone), FGM is criminalised. However, Mauritania's decree (2005) only bans performing the practice on minors in medical facilities. Moreover, laws are often poorly implemented: in Burkina Faso, where FGM has been outlawed since 1996, only seven convictions were recorded in 2012 (UNICEF, 2013).

Despite positive signs that the practice of FGM is declining, rates remain high notably due to its social acceptance. FGM has affected over $46 \%$ of West African women; nine in ten women have been subjected to the practice in Guinea and Mali. In these two countries, acceptance remains high, with respectively $76 \%$ (Guinea) and $72 \%$ (Mali) of women believe that FGM should continue (UNICEF, 2013). The practice is often perceived as a rite of passage for entering adulthood and a determining factor of their marriageability. Furthermore, decisions are often based on pressure from extended families and communities and rarely involve the girl's consent (UNICEF, 2013). Nonetheless, support for FGM appears to be decreasing, particularly among younger generations. In Sierra Leone, 98\% of women aged 45-49 have been cut, compared with 74\% of girls aged 15-19. Among the latter, 57\% think FGM should be continued, compared with $81 \%$ of the former (DHS, 2013). 


\section{Reproductive autonomy}

Women lack reproductive autonomy. One in four women is reported to have an unmet need for family planning, double the world's average. Additionally, women have the lowest level of contraception use (17\% compared with 64\% globally) (UN, 2015b).

Women's lower reproductive autonomy is connected to the poor health service infrastructure in the region. Poor women and women in rural settings face even greater difficulties in accessing reproductive health services, as poverty and remote locations compound their already limited resources (UNFPA, 2012).

$\underline{B o x} 3$

Burkina Faso: The key role of discriminatory social institutions in fertility rates

Women tend to have more children when they are confined to their reproductive role and hence have restricted reproductive autonomy, including low decision-making power over contraceptive use, number and spacing of their children, and limited access to family planning. In Burkina Faso, evidence shows correlations between regions with high fertility rates and prevalence of discriminatory opinions and practices (Figure 8). Acceptance and prevalence of early marriage and adolescent pregnancy are linked with lower levels of education for girls and higher fertility rates.

Figure 8

Higher levels of discrimination in social institutions, higher fertility rates

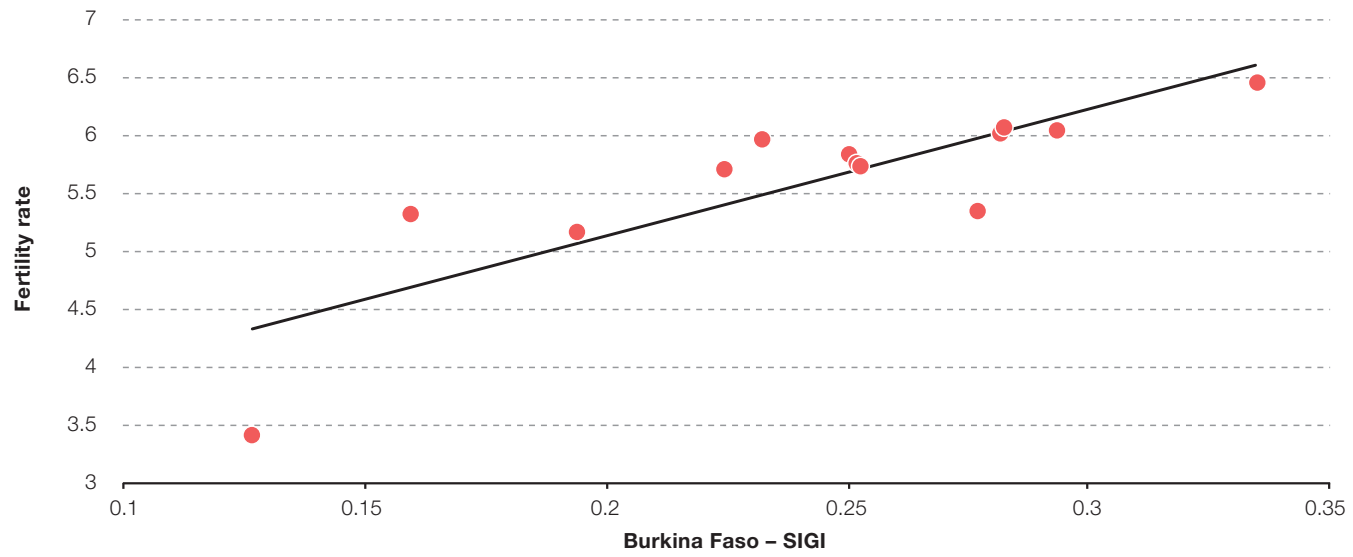

Note: This figure presents the relationship between gender-based discrimination in social institutions (measured by the Burkina Faso-SIGI) and fertility rates (average number of children per woman aged 15-49) at the regional level, controlling for levels of urbanisation, education, income and women's employment rate, age, household size and proportion of Catholics and Muslims in the population.

Sources: DHS (2014), OECD (2018) 


\section{RESTRICTED ACCESS TO RESOURCES AND ASSETS}

$\mathbf{T}$ his sub-index captures discrimination regarding women's rights to access and make decisions over natural and economic resources.

Twelve countries (Benin, Burkina Faso, Chad, Côte d'Ivoire, Gambia, Ghana, Guinea-Bissau, Mauritania, Niger, Nigeria, Sierra Leone and Togo) have shown high to very high levels of discrimination. These results stem primarily from the predominance of discriminatory customary laws and poorly enforced legislative frameworks governing land and property. The countries show significant gender gaps in land and property ownership, with widows particularly vulnerable to property grabbing or disinheritance.

Equality in land, asset ownership and financial access have wide-ranging positive impacts on family nutrition, education, food security, agricultural productivity and women's well-being (van den Bold et al, 2015; Jones et al, 2010). Conversely, low rates of female ownership and decision-making power over land and assets have been correlated with an increased vulnerability to poverty among women and their families and reduced income-generating opportunities for women (FAO, 2011; OECD Development Centre, 2014).

\section{Secure access to land}

Legal equality in most national constitutions and laws has not proven sufficient to counter deeply entrenched discrimination. In all countries, customary law prevents women's secure access to land by blocking their right to either inherit or own land in their names. Although the Liberian property law and the constitution grant women and men equal rights, customary laws favouring male ownership tend to prevail. Benin's Rural Land Code (2007) grants equality in land ownership rights but customary law stipulates that only men can inherit land. Customary law applies in 12 of the 14 districts in Sierra Leone, despite constitutional provisions granting married and unmarried women equal property ownership rights.

Yet, women significantly contribute to agricultural and food production as producers, family labourers and food processors. In Burkina Faso, Cabo Verde, Côte d'Ivoire, Gambia, Guinea, Mali and Senegal (Figure 9), women represent, on average, 43\% of the agricultural labour force but only $8 \%$ of agricultural land owners.

Figure 9

Women's share as agricultural landholders and workers

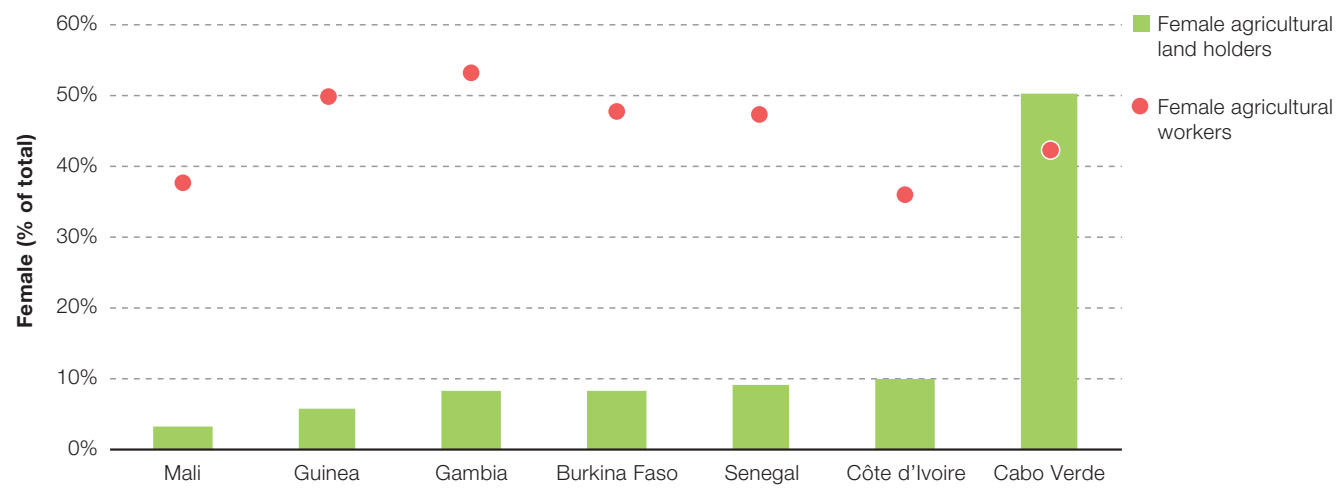

Note: This figure presents the female share of agricultural land holders and of agricultural workers as the percentage of total holders and workers, respectively, by country.

Source: FAO (2011). 
Women's greater share of unpaid care work negatively impact their ability to dedicate time to agricultural activities (World Bank, 2017). In Niger, a positive correlation was shown between the proportion of children in the household and the size of the gender gap in agricultural productivity, to the detriment of women. In contrast, Nigerian men's agricultural outputs actually increase as the number of children in the household grows, possibly due to their ability to mobilise younger household members to work in the field. This inequality may also reflect the relative importance given to male plots versus female plots (World Bank, 2014a). As a result of these obstacles to female economic participation and access to land, women tend to move towards downstream segments of the agro-food value chains (food processing, marketing and catering), where they represent between $72 \%$ and $88 \%$ of the employed (Allen, Heinrigs and Heo, 2018, forthcoming).

Box 4

Unpaid care work and women's participation in the labour market

Women bear the burden of caring responsibilities. On average, the amount of time spent by women on unpaid care work is six times more than the amount spent by men; however, this ratio varies greatly among countries, ranging from 2 times more in Nigeria to 17 times more in Mali. This unequal division is dictated by discriminatory social institutions at the household level, where women are responsible for the majority of household tasks. Inadequate infrastructure also forces families to spend more time collecting water and fuel for cooking. This situation disproportionately affects women and girls, who undertake $71 \%$ of water collection activities in sub-Saharan Africa (UN, 2015a).

The time spent on unpaid care work has a strong negative correlation with female labour force participation rates (Figure 10). These restrictions on women's economic roles have serious macroeconomic consequences, with substantial income losses attributed to gender gaps in the labour market, ranging from 1\% of the GDP in Ghana and Liberia to 31\% of GDP in Nigeria (Cuberes and Teignier, 2013).

Figure 10

Inequality in unpaid care work correlated with inequality in labour force participation

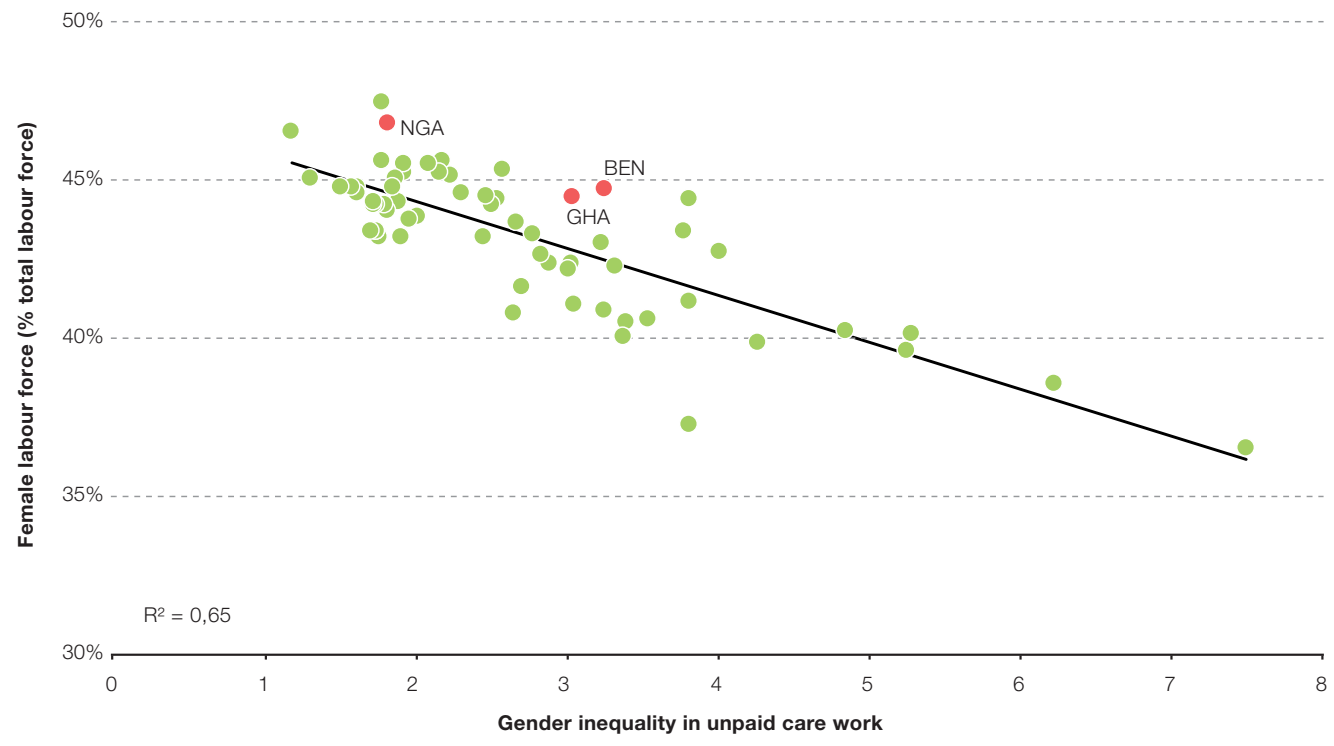

Note: This figure presents the estimated female share of the labour force as a percentage of total labour force by levels of gender inequality in unpaid care work, measured as the female-to-male ratio of time devoted to unpaid care activities, controlling for GDP per capita, fertility rate, urbanisation rate, maternity leave, gender inequality in employment and education and regional characteristics. $\mathrm{R}^{2}=0.65$ means that $65 \%$ of country disparities in female labour force participation are explained by gender inequalities in unpaid care work.

Source: Ferrant, Pesando and Nowacka (2014). 


\section{Secure access to non-land assets}

While most countries guarantee women's legal rights to own and administer non-land assets, legal loopholes and discriminatory practices remain pervasive. In Togo and Côte d'Ivoire, married women can own property and assets independently; however, if the marriage is contracted under a community of property regime, the husband is recognised as the sole legal administrator of the family's property. Indeed, in Togo, only $10 \%$ of women are homeowners compared with $30 \%$ of men (DHS, 2014). Poor legal literacy also constitutes a barrier to women's realisation of their rights; thus, even when legal protection exists, women may not know about it (e.g. Mali) (OCDE, 2014a).

\section{Access to financial services}

More than two-thirds of countries discriminate by law and/or in practice. Banks often demand guarantees that women could rarely bring, or a husband's signature. Illiteracy and lack of business knowledge also complicate women's access to loans (e.g. Liberia). In 2014, 23\% of West African women had bank accounts in financial institutions compared to $36 \%$ of men (World Bank, 2014b). ${ }^{8}$ Facilitating women's access to microfinance is a common strategy to overcome this discrimination.

Figure 11

In Burkina Faso, restrictions on women's access to land further compound restrictions on women's access to financial services

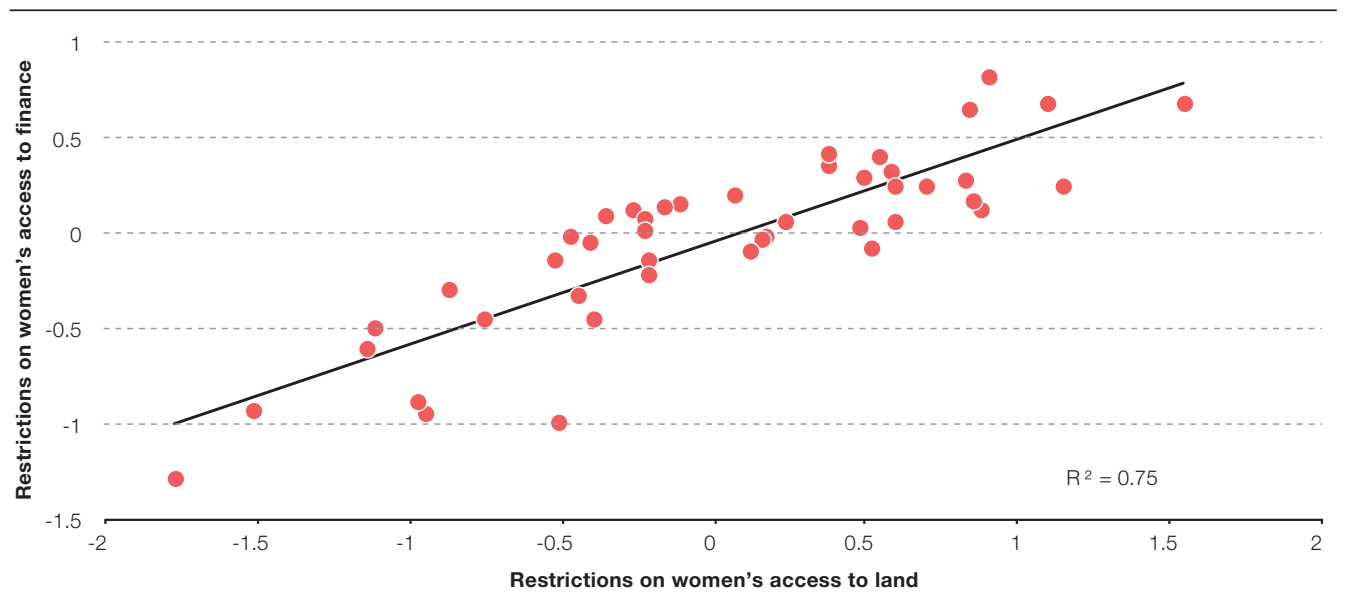

Note: This figure presents the relationship between discrimination against women's right to access land in Burkina Faso and the predicted value of discrimination against women's access to financial services at the provincial level, controlling for levels of poverty, urbanisation and education at the provincial level. A value of -1.5 indicates the minimum level of discrimination, while 0 is the Burkina Faso average and 1.5 the maximum level of discrimination. $R^{2}=0.75$ means that $75 \%$ of provincial disparities in women's access to finance are explained by differences in restrictions on women's access to land.

Source: OECD (2018), Burkina Faso Social Institutions and Gender Index, http://stats.oecd.org.

Box 5

The cost of discrimination on growth and well-being

Discriminatory social institutions negatively affect growth. The current level of gender discrimination in social institutions induces a loss of USD 12 trillion, or $16 \%$ of global income. For West African countries, the total loss is USD 120 billion (Ferrant and Kolev, 2016).

It also impedes well-being. Both women and men are happier when living in a country guaranteeing equal rights and opportunities to both, regardless of country and individual characteristics (Ferrant et al., 2017).
Gender gaps in land and asset ownership compound women's difficulties (Figure 11). Without land or assets, women have a reduced ability to obtain a bank loan due to the need for collateral (O'Sullivan et al, 2014; FAO, 2014). Results from the Women's Empowerment in Agriculture Index confirm that "the top contributor to women's disempowerment is access to and decisions on credit" (Alkire et al, 2013). This has widespread implications for women's economic empowerment, notably their ability to increase or improve farming plots, purchase new technology or start and scale-up an enterprise (O’Sullivan et al; 2014; FAO, 2014). 


\section{RESTRICTED CIVIL LIBERTIES}

7 he sub-index captures laws and practices relative to women's access to public spaces, political voice and participation in public life, including the lack of freedom of movement, the exercise of citizen's right (voting in particular), the inability to run for public office, as well as negative attitudes toward them as public figures or leaders.

Eleven countries (Benin, Chad, Côte d'Ivoire, Gambia, Ghana, Guinea-Bissau, Liberia, Mali, Niger, Nigeria and Sierra Leone) are classified as having high to very high levels of restricted civil liberties. Five countries (Burkina Faso, Guinea, Mauritania, Senegal and Togo) are classified as having low to medium levels of discrimination and no country is positioned at the very low level.

Government-legislated quotas have been important drivers for increasing women's political representation; often under the pressure of civil society organisations. Moreover, the Protocol of the African Charter on Human and Peoples' Rights on the Rights of Women in Africa (2003) endorses measures taken at national and local levels to increase women's political representation. In the African Union's Agenda 2063, governments highlight the importance of removing the "political glass ceiling" that restricts women's progress and impedes full gender parity in elected public offices and managerial positions in both the public and private sectors.

However, discrimination against women in the public sphere persists, including the expression of patriarchal attitudes that justify violence against women. This continues to block women's secure and equal access to public space and restrict their political empowerment.

\section{Access to public space}

Even if legal barriers are lifted, discriminatory practices or informal laws restrict women's secure and equal access to public spaces despite their legal rights in this regard. This is the case in Benin, Burkina Faso, Chad, Gambia, Guinea, Liberia, Mali, Nigeria, Senegal and Sierra Leone. In Burkina Faso, 91\% of the population believe a woman requires her husband's permission to leave the house (OECD, 2018).

\section{Women's political participation}

Six countries (Burkina Faso, Cabo Verde, Guinea, Mauritania, Niger and Senegal) have instituted quotas to promote women's political participation at both national and subnational levels. Sierra Leone has introduced electoral quotas only at the national level. If women's parliamentary representation in the region has increased from 13\% in 2007 to almost 16\% in 2017 (IPU, 2017) ${ }^{9}$, wide discrepancies remain among countries, ranging from 43\% in Senegal to 6\% in Nigeria (IPU, 2017) (Figure 12). Senegal's experience underscores the potential of quotas in fast-tracking women's representation in national parliaments when political will also exists. Senegal witnessed an increase in parliamentary seats held by women, from 23\% in 2012 to 43\% in 2013 after amending its electoral law in 2012, calling for parity on all candidate lists and alternating male and female candidates. However, quotas tend to have no major impact if they are not accompanied by other broader measures that enforce women's position in social institutions (Obamamoye, 2016). 
Figure 12

Women's political representation and quotas

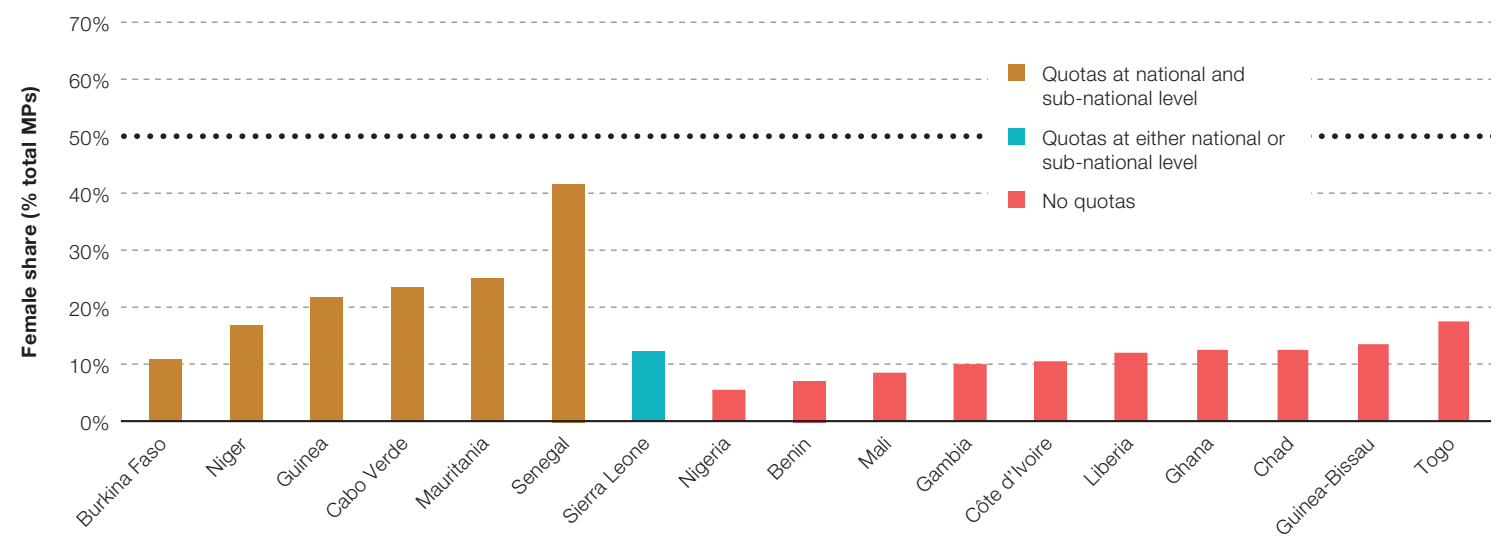

Note: This figure presents the female share of seats in national parliaments by quota status.

Source: OECD (2014a), Gender, Institutions and Development Database, http://stats.oecd.org.

Box 6

Women's political participation and governance

While women's presence in politics and government decision-making structures is a positive outcome for democratic governance institutions, education, infrastructure and health standards, women's inclusion in political leadership positions remains a major challenge. This difficulty is often caused by discriminatory opinions. Negative attitudes towards women as political and community leaders are associated with their lower participation in politics (Figure 13, left panel). Yet, countries having a higher share of women in national parliaments enjoy better governance (Figure 13, right panel).

\section{Figure 13}

Attitudes, women's political participation and governance
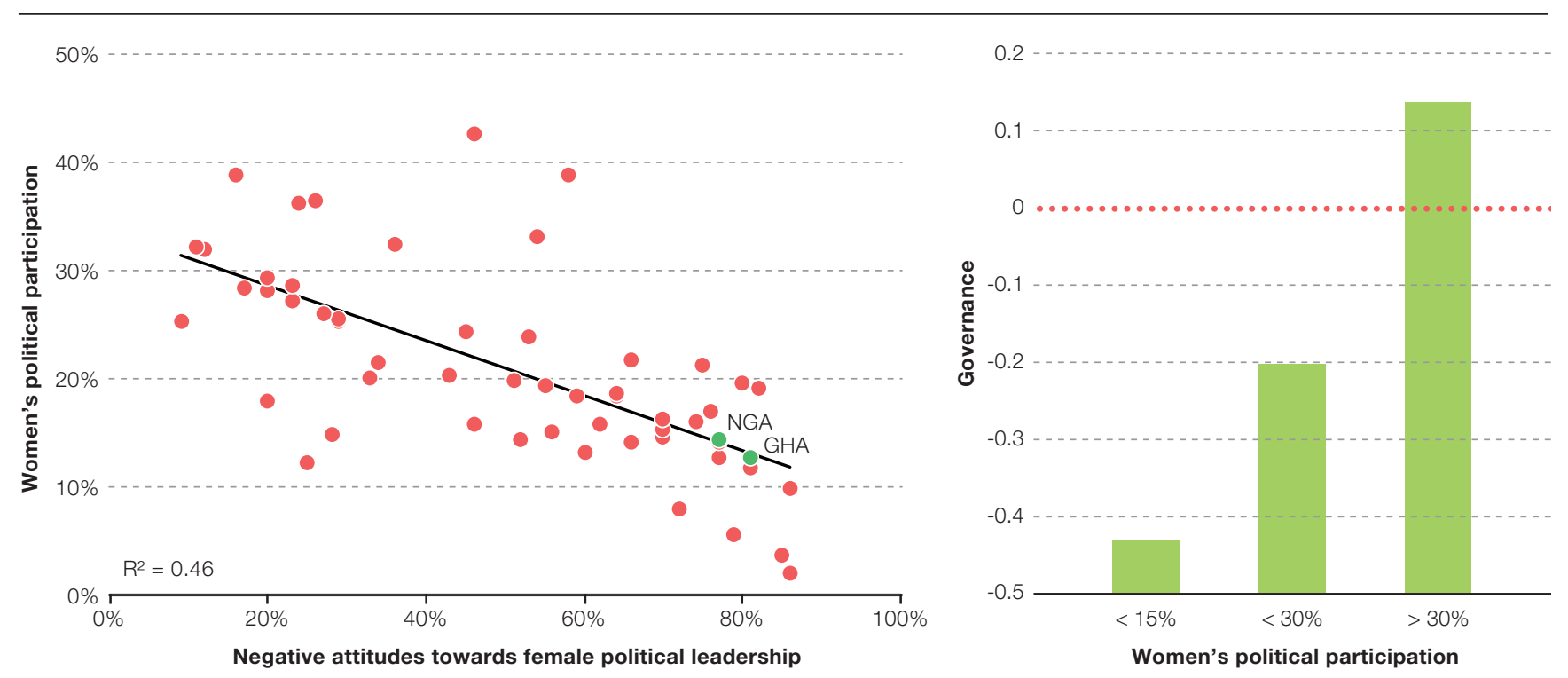

Notes: The left panel presents the relationship between attitudes towards women's political leadership (percentage of the population that thinks men make better political leaders than women) and women's share in national parliament in 100 countries in 2014 controlling for the presence of quotas, regional characteristics and the country income level. An $R^{2}=0.46$ means that $46 \%$ of cross-country disparities in women's political participation are explained by regional differences in attitudes toward female political leadership, regional and income characteristics. The right panel presents the country's level of governance (rule of law and accountability, ranging from -2.5 (weak) to 2.5 (strong) governance), by level of women's political participation. The horizontal line set up at 0 . Countries scoring above this line are likely to have positive measures strengthening women's participation in governance.

Source: OECD (2014a), Gender, Institutions and Development Database, http://stats.oecd.org; World Bank (n.d.), Worldwide Governance Indicators, http://databank.worldbank.org/data/reports.aspx?source=world-development-indicators. 


\section{Rights in the workplace}

In many countries, women still face discrimination in laws restricting their ability to work during night hours (e.g. Sierra Leone) and limiting or prohibiting their right to work in mines (e.g. Chad) or factories (e.g. Benin) (World Bank, 2015). Overall, 60\% of West African countries have more than nine legal provisions restricting women's ability to obtain jobs in the same way as men (Figure 14). In Mauritania, no legislation is in place to protect women against discrimination in hiring or sexual harassment in the workplace.

Figure 14

Stereotypes towards working women and restrictions in access to jobs

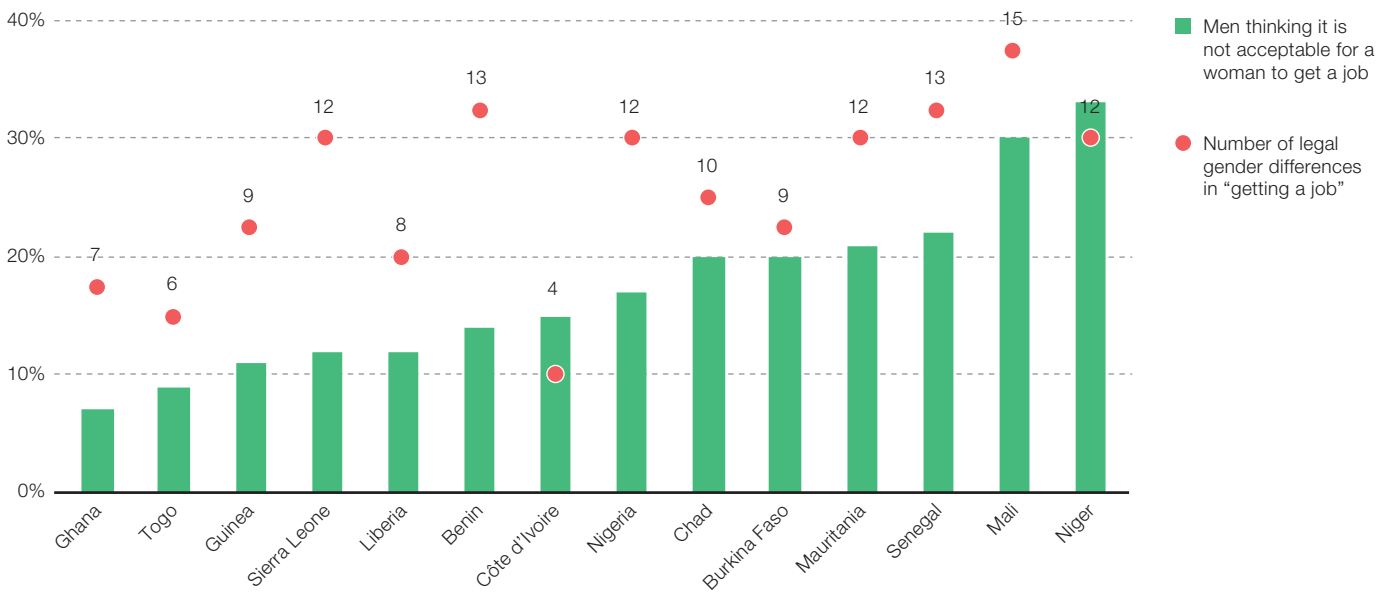

Note: This figure presents the proportion of men considering that it is unacceptable for women in their families to get a paid job outside the home and the number of legal restrictions against women in "getting a job", by country.

Source: Gallup and ILO (2017), Towards a better future for women and work: Voices of women and men www.ilo.org/washington/events/ WCMS_549457/lang--en/index.htm; World Bank (2015), Women Business and the Law 2016: Getting to Equal, http://wbl.worldbank.org/.

Furthermore, discriminatory practices and attitudes towards women's access to employment are persistent. In Nigeria's private sector, many employers force young women to sign job contracts stipulating that they should not become pregnant for the first three years of their employment. Seventeen per cent of West African men think that it is unacceptable for women to work outside the home, and 21\% would prefer that the women in their families stay home rather than work at paid jobs (Gallup and ILO, 2017).

On a positive side, some governments are enhancing their engagement to empower women in the workplace. Côte d'Ivoire, Mali and Sierra Leone have all passed laws on equal remuneration for work of equal value. In Côte d'Ivoire, the government has taken several measures to increase women's participation in the workforce, such as implementing capacity-building initiatives for women responsible for co-operatives, and providing training in leadership and technical and managerial formations (Republic of Côte d'Ivoire, 2014). The Guinean government has implemented a programme aiming to feminise public administration (MSAAWC, 2014). Additionally, the government leads awareness-raising activities to expand women's access to decision-making positions (MSAAWC, 2014). 


\section{NOTES}

1 This paper covers the 15 member countries of the Economic Community of West African States (Benin, Burkina Faso, Cabo Verde, Côte d'Ivoire, Gambia, Ghana, Guinea, Guinea-Bissau, Liberia, Mali, Niger, Nigeria, Senegal, Sierra Leone and Togo), plus Chad and Mauritania.

2 This paper does not dedicate a section to the Son Bias sub-index, as there is no evidence of fertility preferences in West Africa. However, an analysis of the missing women variable will be included in the Restricted Physical Integrity sub-index, highlighting the phenomenon in West African countries.

3 "Achieve gender equality and empower all women and girls".

4 Burkina Faso, Cabo Verde, Côte d'Ivoire, Gambia, Guinea, Mali and Senegal.

5 Burkina Faso, Cabo Verde, Guinea, Mauritania, Niger, Senegal and Sierra Leone.

6 Cabo Verde was not included in the SIGI 2014. It will be covered in the next edition of the SIGI to be launched in 2018

7 Burkina Faso, Chad, Côte d'Ivoire, Gambia, Ghana, Liberia, Mali, Mauritania, Niger, Nigeria and Senegal.

8 These averages exclude Cabo Verde, Gambia, Guinea-Bissau and Liberia.

9 Both averages include the 17 countries. 


\section{REFERENCES}

AfDB (2013), "Côte d'Ivoire: Emerging From Conflict Gender-Based Component of a Multi-sector Support Project", African Development Bank.

AfDB/OECD/UNDP (2017), African Economic Outlook 2017: Entrepreneurship and Industrialisation, OECD Publishing, Paris, http://dx.doi.org/10.1787/aeo-2017-en.

Allen, T., P. Heinrigs and I. Heo (2018), "Agriculture, food and jobs in West Africa", West African Papers, No.14, OECD Publishing, Paris, forthcoming.

Alkire, S. et al. (2013), The Women's Empowerment in Agriculture Index, Oxford Poverty and Human Development Initiative, Working Paper No. 58.

AUC (2015), Agenda 2063: The Africa we want, African Union Commission, Addis Ababa.

Cuberes, D. and M. Teignier (2013), Aggregate Costs of Gender Gaps in the Labor Market: A Quantitative Estimate, Clark University, pp. 1-26.

DHS (n.d.), Demographic and Health Surveys (database), The DHS Program, Rockville, www.statcompiler.com/en/ (accessed October 2017).

Doss, C. et al. (2013), "Gender inequalities in ownership and control of land in Africa. Myth versus reality", IFPRI Discussion Paper 01308.

FAO (2014), The State of Food and Agriculture 2014, Food and Agriculture Organization, Rome.

FAO (2011), The State of Food and Agriculture 2010-11, Food and Agriculture Organization, Rome.

Ferrant, G., A. Kolev and C. Tassot (2017), "The pursuit of happiness: Does gender parity in social institutions matter?", OECD Development Centre Working Papers No. 337, OECD, Paris, http://dx.doi.org/10.1787/f7e0c69c-en.

Ferrant, G. and A. Kolev, (2016), "Does gender discrimination in social institutions matter for longterm growth? Cross-country evidence", OECD Development Centre Working Papers No. 330, OECD, Paris, http://dx.doi.org/10.1787/5jm2hz8dgls6-en.

Ferrant, G. and K. Nowacka (2015), "Measuring the drivers of gender inequality and their impact on development: the role of discriminatory social institutions", Gender and Development, Vol. 23/2, pp. 319-332.

Ferrant, G., L. M. Pesando and K. Nowacka (2014), Unpaid Care Work: The Missing Link in the Analysis of Gender Gaps in Labour Outcomes, OECD Development Centre, Paris.

Gallup and ILO (2017), Towards a better future for women and work: Voices of women and men, Gallup, Inc. and the International Labour Organization.

GEM (2017), Global Entrepreneurship Monitor 2016/17 Global Report, Global Entrepreneurship Monitor.

GEM (2016), Global Entrepreneurship Monitor 2015/16 Global Report, Global Entrepreneurship Monitor.

GEM (2014), Global Entrepreneurship Monitor 2013 Global Report, Global Entrepreneurship Monitor.

Girls not brides (n. d.), Benin, www.girlsnotbrides.org/child-marriage/benin/.

ILO (2014), Maternity and paternity at work: Law and practice across the world, International Labour Organisation, Geneva.

ILO (n.d.), Ratifications of C183 - Maternity Protection Convention, 2000 (No. 183), www.ilo.org/ dyn/normlex/en/f?p=NORMLEXPUB:11300:0::NO::P11300_INSTRUMENT_ID:312328 (accessed October 2017).

Immigration and Refugee Board of Canada (2013), "Liberia: Situation of single or divorced women living alone, particularly in Monrovia; whether they can find work and housing; support services available to them", Canada, http://www.refworld.org/docid/51d41ef94.html.

IPU (2017), Women in politics, Inter-Parliamentary Union and UN Women, Geneva.

Jones, N., C. Harper and C. Watson (2010), Stemming Girls' Chronic Poverty: Catalysing Development Change by Building Just Social Institutions, Chronic Poverty Research Centre, Manchester.

Ministère de la femme, de l'action sociale et de la solidarité nationale [MFASSN] (2015), Feuille de route de lutte contre le mariage des enfants et les mutilations génitales féminines, Burkina Faso.

Ministry for Social Action and the Advancement of Women and Children [MSAAWC] (2014), Rapport de la République de Guinée sur l'évaluation de la mise en oeuvre du programme d'action de Beijing+20, Guinée.

Ministry of Solidarity, Family, Women and Children [MSFWC] (2014), Document de stratégie nationale de lutte contre les violences basées sur le Genre, Côte d'Ivoire. 
Obamamoye, B. F. (2016), "ECOWAS and Women Representation in West Africa", Journal of Political Sciences \& Public Affairs.

O'Sullivan, M et al. (2014), Levelling the field: improving opportunities for women farmers in Africa, World Bank Group, Washington DC.

OECD (2018), Étude pays SIGI Burkina Faso, OECD, Paris.

OECD (2014a), Gender, Institutions and Development Database, http://stats.oecd.org (accessed October 2017).

OECD (2014b), Social Institutions and Gender Index Country Profiles, http://genderindex.org.

OECD Development Centre (2014), Social Institutions and Gender Index Synthesis Report, OECD Publishing, Paris.

Sonke Gender Justice Network and MenEngage (2009), Working with men and boys: Emerging strategies from across Africa to address Gender-based Violence and HIVIAIDS, Sonke Gender Justice Network and MenEngage Network, Johannesburg.

UN Committee on the Elimination of Discrimination Against Women (CEDAW) (2014), List of issues and questions in relation to the combined third to seventh periodic reports of Senegal, 17 November 2014.

UN Women (2016), Progress of the World's women 2015-2016, UN Women, United States.

UN Women (2015), Preventing Conflict, Transforming Justice, Securing the Peace, UN Women, United States.

UIS (n.d.), Education: Participation, UN Institute for Statistics Database, http://data.uis.unesco.org/ (accessed October 2017).

UNFPA (2012), Joint Programme on Female Genital Mutilation/Cutting: Accelerating Change, UNFPA-UNICEF, New York.

UNICEF (2015), Child marriage, Adolescent pregnancy and Family formation in West and Central Africa, UNICEF, New York.

UNICEF (2013), Female Genital Mutilation/Cutting: A statistical overview and exploration of the dynamics of change, The United Nations Children's Fund, New York.

United Nations (2015a), "Extreme poverty and human rights", Note by the Secretary-General, Sixtyeighth session of the UN General Assembly, A/68/293.

United Nations (2015b), Trends in Contraceptive Use Worldwide 2015, United Nations, Department of Economic and Social Affairs, Population Division.

United Nations (2015c), Transforming our world: the 2030 Agenda for Sustainable Development, United Nations General Assembly, Resolution adopted 25 September 2015.

US Department of State (2017), 2016 Country Reports on Human Rights Practices, United States Department of State, Bureau of Democracy, Human Rights and Labor.

US Department of State (2012), "2012 Country Reports on Human Rights: Lesotho", United States Department of State, Bureau of Democracy, Human Rights and Labor.

Van den Bold, M. et al. (2015), "Can integrated Agriculture-Nutrition Programmes Change Gender Norms on Land and Asset Ownership? Evidence from Burkina Faso", The Journal of Development Studies, Vol. 51:9, pp. 1155-1174.

World Bank (2017), "Time and money: a study of labor constraints for female cotton producers in Côte d'Ivoire", World Bank, Washington, DC.

World Bank (2015), Women Business and the Law 2016: Getting to Equal, World Bank, Washington, DC.

World Bank (2014a), Levelling the field: Improving opportunities for women farmers in Africa, World Bank, Washington, DC.

World Bank (2014b), Global Financial Inclusion Database, World Bank, Washington, DC, http:// databank.worldbank.org/data/reports.aspx? source=1228 (accessed October 2017).

World Bank (2012), World Development Report 2012: Gender Equality and Development, World Bank, Washington, DC

World Bank (n.d.), Worldwide Governance Indicators (database), World Bank, Washington, DC, http://info.worldbank.org/governance/wgi/index.aspx\#home (accessed October 2017).

World Bank (n.d.), World Development Indicators (database), World Bank, Washington, DC, http:// data.worldbank.org/indicator (accessed October 2017).

WHO (2017), "Violence against women", World Health Organization, www.who.int/. 


\section{ANNEX 1: DESCRIPTION OF THE SIGI}

The Social Institutions and Gender Index (SIGI) measures gender-based discrimination in social norms, practices and laws across 160 countries. The SIGI comprises country profiles, a classification of countries and a database; it serves as a research, advocacy and evidence-based policy tool for policy makers and the development community.

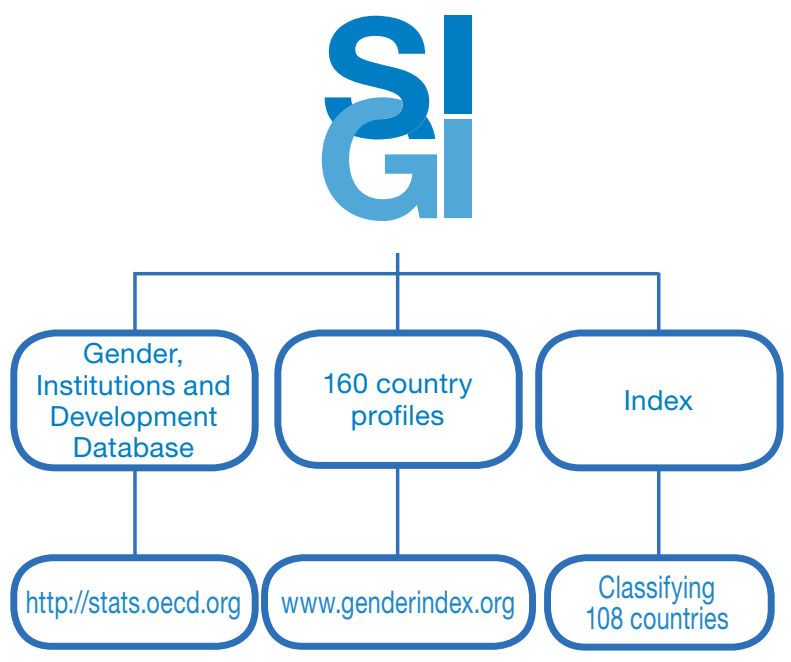

Note: As a composite index, SIGI scores countries on 14 indicators, grouped into five sub-indices. SIGI ranges between 0 (no inequality) and 1 (complete inequality). The index classifies countries into five groups, from those with very low levels of discrimination in social institutions to those with very high levels.

It covers five dimensions, spanning major socio-economic areas that affect the life course of women and girls': discriminatory family code, restricted physical integrity, son bias, restricted access to resources and assets, and restricted civil liberties. These dimensions look at the gaps that legislation, prevalence and attitudes and practices create between women and men in terms of rights and opportunities. 


\section{ANNEX 2: SIGI RESULTS PER SUB-INDEX FOR WEST AFRICAN COUNTRIES}

\begin{tabular}{|c|c|c|c|c|c|c|c|c|c|c|c|}
\hline Country & SIGI & \multicolumn{2}{|c|}{$\begin{array}{l}\text { Discriminatory } \\
\text { family code }\end{array}$} & \multicolumn{2}{|c|}{$\begin{array}{l}\text { Restricted physical } \\
\text { integrity }\end{array}$} & \multicolumn{2}{|c|}{ Son bias } & \multicolumn{2}{|c|}{$\begin{array}{c}\text { Restricted re- } \\
\text { sources and assets }\end{array}$} & \multicolumn{2}{|c|}{$\begin{array}{l}\text { Restricted civil } \\
\text { liberties }\end{array}$} \\
\hline \multicolumn{12}{|c|}{ Medium levels of discrimination in the SIGI } \\
\hline Togo & 0,1860 & 0,3696 & medium & 0,5488 & high & 0,1326 & medium & 0,5913 & high & 0,3539 & medium \\
\hline Senegal & 0,1985 & 0,5931 & very high & 0,6337 & high & 0,0888 & low & 0,4076 & medium & 0,2554 & low \\
\hline Guinea-Bissau & 0,2110 & 0,4073 & medium & 0,4932 & high & 0,0713 & low & 0,5913 & high & 0,5399 & high \\
\hline
\end{tabular}

High levels of discrimination in the SIGI

\begin{tabular}{|c|c|c|c|c|c|c|c|c|c|c|c|}
\hline Côte d'Ivoire & 0,2537 & 0,4955 & high & 0,5895 & high & 0,1858 & medium & 0,5913 & high & 0,5399 & high \\
\hline Benin & 0,2780 & 0,2763 & medium & 0,4432 & high & 0,3677 & high & 0,5913 & high & 0,7953 & very high \\
\hline Burkina Faso & 0,2819 & 0,5419 & high & 0,7257 & very high & 0,1910 & medium & 0,5913 & high & 0,4505 & medium \\
\hline Ghana & 0,2988 & 0,3946 & medium & 0,5491 & high & 0,3136 & high & 0,8044 & very high & 0,5399 & high \\
\hline Guinea & 0,3206 & 0,5413 & high & 0,9515 & very high & 0,2253 & medium & 0,3885 & medium & 0,4505 & medium \\
\hline
\end{tabular}

Very high levels of discrimination in the SIGI

\begin{tabular}{|c|c|c|c|c|c|c|c|c|c|c|c|}
\hline Sierra Leone & 0,3720 & 0,3309 & medium & 0,8550 & very high & 0,0364 & very low & 0,8044 & very high & 0,6093 & high \\
\hline Liberia & 0,3828 & 0,5669 & very high & 0,8907 & very high & 0,0236 & very low & 0,4076 & medium & 0,7953 & very high \\
\hline Nigeria & 0,3911 & 0,6723 & very high & 0,4766 & high & 0,2494 & high & 0,7626 & very high & 0,7953 & very high \\
\hline Mauritania & 0,3954 & 0,7556 & very high & 0,9939 & very high & 0,1746 & medium & 0,5913 & high & 0,1951 & low \\
\hline Niger & 0,4415 & 1,0000 & very high & 0,4059 & medium & 0,1746 & medium & 0,5913 & high & 0,8140 & very high \\
\hline Chad & 0,4665 & 0,9705 & very high & 0,8185 & very high & 0,0014 & very low & 0,5913 & high & 0,6093 & high \\
\hline Mali & 0,5164 & 0,8309 & very high & 1,0000 & very high & 0,3048 & high & 0,4076 & medium & 0,7953 & very high \\
\hline Gambia & 0,5240 & 0,5131 & high & 0,8509 & very high & 0,0000 & very low & 1,0000 & very high & 0,7953 & very high \\
\hline
\end{tabular}

Not ranked in the SIGI

\begin{tabular}{|c|c|c|c|c|c|c|}
\hline Cabo Verde & n. a. & n. a. & n. a. & n. a. & n. a. & n. a. \\
\hline
\end{tabular}

${ }^{*}$ n.a.: not available 


\section{ANNEX 3: RATIFICATIONS OF GLOBAL AND REGIONAL PROTOCOLS ON GENDER EQUALITY}

\begin{tabular}{|c|c|c|c|c|c|c|}
\hline Country & $\begin{array}{l}\text { Convention on the } \\
\text { Elimination of } \\
\text { Violence against } \\
\text { Women (CEDAW) }\end{array}$ & $\begin{array}{l}\text { Optional Protocol } \\
\text { to the Convention } \\
\text { on the Elimination } \\
\text { of All Forms of } \\
\text { Discrimination } \\
\text { against Women }\end{array}$ & $\begin{array}{c}\text { Protocol to the } \\
\text { African Charter on } \\
\text { Human and } \\
\text { Peoples' Rights on } \\
\text { the Rights of } \\
\text { Women in Africa } \\
\text { (Maputo Protocol) }\end{array}$ & $\begin{array}{l}\text { The African } \\
\text { Charter on the } \\
\text { Rights and } \\
\text { Welfare of the } \\
\text { Child }\end{array}$ & $\begin{array}{l}\text { The African Youth } \\
\text { Charter }\end{array}$ & $\begin{array}{c}\text { C183 - Maternity } \\
\text { Protection } \\
\text { Convention } \\
\text { (No. 183) }\end{array}$ \\
\hline Benin & Ratified & Signed & Ratified & Ratified & Signed & Ratified \\
\hline Burkina Faso & Ratified & Ratified & Ratified & Ratified & Ratified & Ratified \\
\hline Cabo Verde & Ratified & Ratified & Ratified & Ratified & n.a. & n.a. \\
\hline Chad & Ratified & Signed & Ratified & Ratified & Signed & n.a. \\
\hline Côte d'Ivoire & Ratified & Ratified & Ratified & Ratified & Ratified & n.a. \\
\hline Gambia & Ratified & n.a. & Ratified & Ratified & Ratified & n.a. \\
\hline Ghana & Ratified & Ratified & Ratified & Ratified & Signed & n.a. \\
\hline Guinea & Ratified & n.a. & Ratified & Ratified & Signed & n.a. \\
\hline Guinea-Bissau & Ratified & Ratified & Ratified & Signed & Ratified & n.a. \\
\hline Liberia & Ratified & Signed & Ratified & Signed & Signed & n.a. \\
\hline Mali & Ratified & Ratified & Ratified & Ratified & Ratified & Ratified \\
\hline Mauritania & Ratified & n.a. & Ratified & Ratified & n.a. & n.a. \\
\hline Niger & Ratified & Ratified & Signed & Ratified & Ratified & n.a. \\
\hline Nigeria & Ratified & Ratified & Ratified & Ratified & Ratified & n.a. \\
\hline Senegal & Ratified & Ratified & Ratified & Ratified & Ratified & $\begin{array}{c}\text { In force on } \\
18 \text { April } 2018\end{array}$ \\
\hline Sierra Leone & Ratified & Signed & Signed & Ratified & Signed & n.a. \\
\hline Togo & Ratified & n.a. & Ratified & Ratified & Ratified & n.a. \\
\hline
\end{tabular}




\section{GLOSSARY}

Social institutions set the parameters for which decisions, choices or behaviours are deemed acceptable or unacceptable for women and men in a society. As such, these institutions define women's and men's roles and influence their outcomes.

Discriminatory social institutions are formal and informal laws, social norms and practices that restrict or exclude women and consequently limit their access to rights, justice, resources and empowerment opportunities.

Early marriage is defined as a formal marriage or informal union before the recommended minimum age of 18 established within international declarations and conventions.

Unpaid care work refers to non-remunerated household activities, such as childcare, collecting water and firewood and housework. 




\section{ALSO IN THE WEST AFRICAN PAPERS SERIES:}

Allen, T. and P. Heinrigs (2016), "Emerging Opportunities in the West African Food Economy", West African Papers, No. 1, OECD Publishing, Paris. http://dx.doi.org/10.1787/5jlvfj4968jb-en

Lewis, K. and C. Buontempo (2016), "Climate Impacts in the Sahel and West Africa: The Role of Climate Science in Policy Making", West African Papers, No. 2, OECD Publishing, Paris. http://dx.doi.org/10.1787/5jlsmktwjcd0-en

Gnisci, D. (2016), “Women's Roles in the West African Food System: Implications and Prospects for Food Security and Resilience", West African Papers, No. 3, OECD Publishing, Paris. http://dx.doi.org/10.1787/5jlpl4mh1hxn-en

Staatz, J. and F. Hollinger (2016), "West African Food Systems and Changing Consumer Demands", West African Papers, No. 4, OECD Publishing, Paris. http://dx.doi.org/10.1787/b165522b-en

Prieto Curiel, R., P. Heinrigs and I. Heo (2017), "Cities and Spatial Interactions in West Africa: A Clustering Analysis of the Local Interactions of Urban Agglomerations", West African Papers, No. 5, OECD Publishing, Paris. http://dx.doi.org/10.1787/57b30601-en

Walther, O. (2017), "Cross-border Co-operation Networks in West Africa”, West African Papers, No. 06, OECD Publishing, Paris. http://dx.doi.org/10.1787/73298292-en

Ibrahim, I.Y. (2017), “The Wave of Jihadist Insurgency in West Africa: Global Ideology, Local Context, Individual Motivations", West African Papers, No. 07, OECD Publishing, Paris. http://dx.doi.org/10.1787/eb95c0a9-en

Allen, T. (2017), "The cost of high food prices in West Africa", West African Papers, No. 08, OECD Publishing, Paris. http://dx.doi.org/10.1787/c2db143f-en

van Den Hoek, J. (2017), "Agricultural market activity and Boko Haram attacks in northeastern Nigeria", West African Papers, No.09, OECD Publishing, Paris. http://dx.doi.org/10.1787/13ba9f2e-en

Walther, O. (2017), "Wars and Conflicts in the Sahara-Sahel", West African Papers, No. 10, OECD Publishing, Paris. https://doi.org/10.1787/8bbc5813-en

Elisher, S. (2018), "Defying the Odds? Nigerien Responses to Foreign and Domestic Security Challenges", West African Papers, No. 11, OECD Publishing, Paris. https://doi.org/10.1787/104d1c6d-en

Eizenga, D. (2018), "The Unstable Foundations of Political Stability in Chad", West African Papers, No. 12, OECD Publishing, Paris. https://doi.org/10.1787/508844d3-en

For more information on the series, please contact: lia.beyeler@oecd.org 